Article

\title{
Determinants of Sino-ASEAN Banking Efficiency: How Do Countries Differ?
}

\author{
Hasanul Banna 1,2**i), Syed Karim Bux Shah ${ }^{3} \mathbb{D}$, Abu Hanifa Md Noman ${ }^{4,5}$, Rubi Ahmad ${ }^{4}$ and $^{4}$ \\ Muhammad Mehedi Masud ${ }^{6}$ \\ 1 Ungku Aziz Centre for Development Studies, Faculty of Economics and Administration, \\ University of Malaya, 50603 Kuala Lumpur, Malaysia \\ 2 Putra Business School, University Putra Malaysia (UPM), 43400 Serdang, Selangor, Malaysia \\ 3 Institute of Business Administration, University of Sindh, Jamshoro 76080, Pakistan; \\ kbsayed@usindh.edu.pk \\ 4 Department of Finance and Banking, Faculty of Business and Accountancy, University of Malaya, \\ 50603 Kuala Lumpur, Malaysia; abuhanifa@iiuc.ac.bd (A.H.M.N.); rubi@um.edu.my (R.A.) \\ 5 Department of Business Administration, Faculty of Business Studies, International Islamic University \\ Chittagong, 4318 Kumira, Bangladesh \\ 6 Department of Development Studies, Faculty of Economics and Administration, University of Malaya, \\ 50603 Kuala Lumpur, Malaysia; mehedi@um.edu.my \\ * Correspondence: bannaje@yahoo.com or banna@um.edu.my; Tel.: +6-03-7967-3602
}

Received: 12 September 2018; Accepted: 30 January 2019; Published: 20 February 2019

check for updates

\begin{abstract}
The purpose of this paper is to assess the importance of geographical location in the banking sector efficiency of the Sino-ASEAN (Association of Southeast Asian Nations) region, and how the location was affected before, during and after the financial crisis. Using a panel of data from 407 banks from China, Indonesia, Malaysia, the Philippines, Singapore, Thailand and Vietnam from 2000-2013, this study applies data envelopment analysis, Tobit regression, bootstrapping, and Simar and Wilson double bootstrapping regression. The empirical evidence suggests that the banking market has an important and significant role in the efficiency of the banking sector in the Sino-ASEAN region. The significant country's coefficients suggest that during the pre-crisis period, banks belonging to China and Indonesia were more likely to be efficient due to the geographical location effect. The study finds the same tendency among Chinese banks in the crisis period as in the period before the crisis. Overall, the results suggest that Chinese banks outperform banks from the ASEAN countries in terms of efficiency. This study raises some significant policy implications for improving bank efficiency.
\end{abstract}

Keywords: Efficiency; DEA; China; ASEAN; banking; financial crisis; geographical location

JEL Classification: G01; G21

\section{Introduction}

The banking sectors of the East Asian countries are homogenous for at least three reasons: Firstly, the commercial banks are predominant sources of financial assets, holding more than 80 percent of the region's financial assets (Chan et al. 2015). Secondly, the governments promote banking sector consolidation in the region through mergers/acquisitions to boost banking sector stability (Soedarmono et al. 2013). Thirdly, the countries have liberalized their entry barriers for regional banks to promote regional banking integration through the adoption of regional integration frameworks, such as the Association of Southeast Asian Nations (ASEAN) Banking Integration Framework (ABIF) in March 2015, the ASEAN-China Free Trade Area (FTA) in January 2010 and the ASEAN Plus Three cooperation in December 1997. The ASEAN Plus Three cooperation includes China, Japan and South 
Korea (Chan et al. 2015; Noman et al. 2018). The banking sector liberalization and regional banking integration frameworks were initiated in order to promote competition and encourage banks to increase their operational efficiency (Noman et al. 2017). In a competitive market, banks need to be efficient in order to enjoy competitive advantages over inefficient banks (Schaeck and Cihák 2014). In addition, Kwack (2000) and Molyneux et al. (2013) indicated that operational inefficiency was among the leading causes of bank failure during the Asian Financial Crisis (AFC) and the global financial crisis (GFC). Consequently, the determination of East Asian banks' operational efficiency has gained considerable attention from academics and policy-makers. Additionally, the GFC in both advanced and transition economies and the associated fiscal cost of crisis resolution (Honohan and Klingebiel 2003) has generated a new wave of interest among researchers to re-examine bank efficiency.

Bank efficiency has already gained a considerable amount attention in banking literature, however, most studies focus on the United States and other developed Western countries (such as Athanasoglou et al. 2008; Fries and Taci 2005; Heffernan and Fu 2010; Nurboja and Košak 2017; Qin and Pastory 2012, among others). In recent years, several studies have been undertaken on different issues relating to the efficiency of East Asian banks, but most of them have been focused on a single country. Dacanay (2007) and Manlagñit (2011) in the Philippines, Sufian (2009) in Malaysia and Margono et al. (2010) in Indonesia focused on the effect of the AFC on bank efficiency. Another group of studies by Berger et al. (2009) in China, Parinduri and Riyanto (2014), Margono et al. (2010), Hadad et al. (2011a) and Hadad et al. (2011b) in Indonesia, Matthews and Ismail (2006) in Malaysia, and Vu and Nahm (2013) in Vietnam focused on the effect of ownership structure on efficiency. Zhang and Matthews (2012) focused on post-AFC efficiency convergence in Indonesia, and Chen et al. (2005) investigated the effect of Chinese banking reform on efficiency, while Dong et al. (2014) estimated cost efficiency in China. In addition, Sufian and Habibullah (2009) investigated the effect of mergers and acquisitions on the efficiency of banks in Malaysia. In another study, Sufian and Habibullah (2010) investigated the determinants of efficiency in banks in Thailand.

Cross-country bank efficiency studies in East Asian countries are still scarce in the literature. Abd Karim (2001) made the first attempt in determining the bank efficiency of four East Asian countries: Indonesia, Malaysia, the Philippines and Thailand. In another study, Williams and Nguyen (2005) investigated financial liberalization and profit efficiency in AFC-affected countries, such as Indonesia, Malaysia, the Republic of Korea and the Philippines. In addition, Thoraneenitiyan and Avkiran (2009) investigated the role of consolidation and liberalization on efficiency in Indonesia, Malaysia, the Philippines, Thailand and Korea, while Sufian (2010) investigated the effect of the AFC on technical efficiency in Malaysia and Thailand. Most recently, Chan et al. (2015) investigated the effect of market structure and institutional quality on efficiency in Indonesia, Malaysia, the Philippines, Singapore and Thailand.

The present study aims to determine the efficiency of banks and the determinants of said efficiency across East Asian countries, especially ASEAN-6 ${ }^{1}$ countries and China (hereafter Sino-ASEAN). This is due to the fact that the cross-country comparison of bank efficiency enables us to answer fundamentally essential research questions, such as: Do countries differ in terms of their banking efficiency? This study goes beyond the scope of previous cross-country studies in East Asia, incorporating China into the cross-country study. The findings of this study would be interesting for investors and policymakers in the region, particularly in the context of the full execution of the ASEAN-China FTA and the ASEAN Plus Three cooperation. In addition, cross-country efficiency information in the region is crucial for regional banks in order to move across the region by establishing foreign branches in other countries within the region. The ASEAN banking integration framework, the ASEAN-China FTA and the ASEAN Plus Three cooperation will intensify both regional banking integration and banking market competition in the region. The Asian Development Bank (ADB, ASEAN 2013) identified that diversity is the main characteristic of East Asian banks which is different in the form of the size of economy, industrial structure and stage of

1 Indonesia, Malaysia, Philippines, Singapore, Thailand and Vietnam. 
economic development. Economic diversity may influence large regional banks from relatively developed countries with comparatively low profit margins to move to comparatively less developed countries with a relatively high profit margin (Noman et al. 2017). This study further estimates the effect of the GFC on the efficiency of commercial banks in China and ASEAN countries. This is important to identify whether a given bank suffered from the GFC due to inefficiencies in the region.

This study contributes to banking literature in a number of ways. The study enhances the literature on estimating and comparing the technical efficiency of Sino-ASEAN banks, especially during the GFC period. Firstly, this study estimates the efficiency of Sino-ASEAN countries using a non-parametric data envelopment analysis (DEA) approach. Secondly, it uses second step analysis by estimating the bank specific and country specific determinants on bank efficiency using Tobit regression and Simar and Wilson (2007) double bootstrapping regression. Thirdly, it incorporates the geographical location effect to investigate the role of location on efficiency in the region. Fourthly, it examines the effect of the GFC on efficiency. The study finds that Chinese banks dominate the Sino-ASEAN efficiency frontier regardless of the period, suggesting that Chinese banks outperform ASEAN countries' banks in terms of efficiency, though the efficiency of Chinese banks has sharply declined over the GFC period. Our results also support the hypothesis that location or the banking market has an important and significant role in explaining banking sector efficiency in the Sino-ASEAN region. The significantly positive location coefficients in our model suggest that during the pre-crisis period, banks belonging to China and Indonesia were more likely to be efficient due to the location effect. We found the same tendency among Chinese banks in the crisis period as in the period before the crisis.

The rest of the paper comprises the following sections: Section 2 discusses the data and methods, Section 3 presents the results and discussion, and the final section deals with our conclusion and recommendation.

\section{Methodology}

\subsection{Data and Variables}

In the present international setting, the need for comparable data from different countries imposes substantial restrictions on the type of variables one is able to use, not least because of the various accounting criteria used in the seven countries under investigation. To minimize any possible bias arising from different accounting practices, broad variable definitions have been chosen, as presented by Orbis Bank Focus (OBF), formerly known as Bankscope. The data of bank-specific variables from a sample of 716 banks from Sino-ASEAN countries (total active banks for these seven countries, where six countries were from the ASEAN) was extracted from the OBF database. The data for the macroeconomic variables was extracted from the World Bank (2014) database. Table 1 shows the variable definition used in our analysis, both in DEA, Tobit regression, bootstrapping Tobit and the Simar and Wilson (2007) double bootstrapped procedure. We selected China and the above six ASEAN countries based on their contribution to the entire ASEAN banking industry (based on total assets) and the availability of data. In order to maintain consistency across countries, only commercial banks were included in the analysis. The result is a panel sample of 407 banks with 2870 bank-year observations. The data were extracted from the nonconsolidated income statement and balance sheet data for the years 2000-2013. The percentage of the total number of banks for each country in the sample is summarized in Table 2. Tables 3 and 4 show the descriptive statistics of the variables used in the DEA estimation and regression analysis. All data are reported in USD (million). We split the period into three parts: 2000-2006 as the pre-global financial crisis period, 2007-2009 as the global financial crisis period and 2010-2013 as the post-financial crisis period. We did this in order to show the impact of the GFC on Sino-ASEAN banking industry efficiency. For banks with missing information, we have looked at the individual bank's websites to determine the appropriate classification. Finally, we calculated the efficiency score year by year and we obtained different observations in different years, which are mentioned in Table 5. 
Table 1. Definition of variables.

\begin{tabular}{ccc}
\hline Variables & Definition & Data Source \\
\hline Interest expenses & Panel A: Input-Output Variables & \\
Bonk's interest expense at the end of the year & Orbis Bank Focus (OBF) \\
Personnel expenses & OBF \\
Deposits & Bank's non-interest expense at the end of the year & OBF \\
Loans & Bank's personnel expense at the end of the year & OBF \\
Liquid assets & Bank's deposit at the end of the year & OBF \\
Other earning assets & Bank's loans at the end of the year & OBF \\
& Bank's liquid assets at the end of the year & OBF \\
\hline Bank efficiency & Bank's other earning assets at the end of the year & DEA estimation \\
Total assets & Panel B: Variables Used in Regression & OBF \\
Bank size & Data envelopment analysis (DEA) input-oriented variable return to scale score & Own calculation \\
Return on average assets (ROAA) & Bank's total assets at the end of the year & OBF \\
Capital adequacy ratio (CAR) & The natural logarithm of bank's total assets & OBF \\
Net Interest margin (NIM) & Bank's return on average assets at the end of the year in percentage & OBF \\
GDP growth & Bank's total equity to total assets at the end of the year in percentage & Bank's net interest margin at the end of the year in percentage \\
Inflation rate & Gross domestic product (GDP) growth of the country at the end of the year in percentage & World Bank database \\
Real interest rate & Inflation rate of the country at the end of the year in percentage (Consumer prices) & World Bank database \\
Real interest rate of the country at the end of the year in percentage & World Bank database \\
\hline
\end{tabular}

Table 2. Total number of banks for each country in the sample.

\begin{tabular}{ccc}
\hline Country & Number of Banks & Percentage \\
\hline China & 169 & 41.52 \\
Indonesia & 69 & 16.95 \\
Malaysia & 34 & 8.35 \\
Philippines & 44 & 10.81 \\
Singapore & 20 & 4.91 \\
Thailand & 23 & 5.65 \\
Vietnam & 48 & 11.79 \\
Total & 407 & 100 \\
\hline
\end{tabular}

Table 3. Descriptive statistics of input and output variables used in data envelopment analysis (DEA) estimation.

\begin{tabular}{|c|c|c|c|c|c|c|c|c|c|}
\hline \multicolumn{10}{|c|}{ Input-Output Variable's Descriptive Statistics (Country Wise, Millions USD) } \\
\hline \multicolumn{10}{|c|}{ Input } \\
\hline \multirow[t]{2}{*}{ Country } & \multirow[t]{2}{*}{ Obs. } & \multicolumn{2}{|c|}{ Interest Expenses } & \multicolumn{2}{|c|}{ Non-Interest Expenses } & \multicolumn{2}{|c|}{ Personnel Expenses } & \multicolumn{2}{|c|}{ Deposits } \\
\hline & & Mean & SD & Mean & SD & Mean & SD & Mean & SD \\
\hline China & 1040 & 1653.87 & 5501.74 & 877.54 & 3141.93 & 464.54 & 1800.26 & $78,598.17$ & $278,448.20$ \\
\hline Indonesia & 657 & 170.23 & 327.73 & 133.68 & 284.84 & 63.22 & 138.53 & 3334.25 & 7199.38 \\
\hline Philippines & 214 & 90.35 & 108.45 & 145.69 & 196.00 & 55.63 & 79.93 & 3936.11 & 5611.68 \\
\hline Singapore & 112 & 511.46 & 822.03 & 498.14 & 798.26 & 263.13 & 426.12 & $35,049.76$ & $58,726.01$ \\
\hline Thailand & 243 & 289.06 & 313.59 & 318.67 & 367.83 & 134.72 & 169.30 & $12,683.09$ & $14,689.56$ \\
\hline Vietnam & 334 & 192.63 & 346.06 & 58.40 & 115.07 & 26.91 & 66.50 & 2834.28 & 4704.90 \\
\hline All & 2870 & 730.32 & 3396.91 & 425.21 & 1940.69 & 218.56 & 1108.02 & $33,114.47$ & $171,732.40$ \\
\hline China & 1040 & $48,029.29$ & $167,162.80$ & $17,262.27$ & $53,159.06$ & $33,838.23$ & $113,313.30$ & & \\
\hline Indonesia & 657 & 2182.01 & 4894.53 & 979.17 & 2068.89 & 1487.23 & 3352.61 & & \\
\hline Malaysia & 270 & 6109.30 & $13,835.53$ & 2433.97 & 3800.20 & 2675.53 & 5565.31 & & \\
\hline Philippines & 214 & 2071.67 & 3322.00 & 1170.95 & 1713.31 & 2215.81 & 2958.32 & & \\
\hline Singapore & 112 & $24,059.95$ & $42,799.21$ & 9504.42 & $14,579.68$ & $17,651.27$ & $28,454.28$ & & \\
\hline Thailand & 243 & $10,405.76$ & $11,975.90$ & 2158.42 & 2823.07 & 4029.21 & 5179.20 & & \\
\hline Vietnam & 334 & 1855.47 & 3698.95 & 815.33 & 1117.18 & 1095.13 & 1486.64 & & \\
\hline All & 2870 & $20,668.96$ & $103,316.80$ & 7444.30 & $33,052.04$ & $14,176.75$ & $70,136.62$ & & \\
\hline
\end{tabular}


Table 4. Descriptive statistics of the variables used in regression.

\begin{tabular}{ccccccc}
\hline Variable & Observations & Mean & Std. Dev. & Median & $\mathbf{2 5 \%}$ & $\mathbf{7 5 \%}$ \\
\hline Bank efficiency & & 0.637 & 0.268 & 0.630 & 0.399 & 0.900 \\
Total assets (mill USD) & $39,397.330$ & $196,885.100$ & 3368.169 & 845.261 & $12,016.380$ \\
Bank size (log total assets) & & 8.110 & 2.085 & 8.122 & 6.740 & 9.394 \\
Return on average assets & \multirow{2}{*}{2870} & 12.470 & 11.852 & 9.117 & 0.622 & 1.564 \\
Capital adequacy ratio & & 3.751 & 2.981 & 3.265 & 2.343 & 14.057 \\
Net interest margin (\%) & & 6.956 & 2.902 & 6.486 & 5.318 & 4.421 \\
GDP growth (\%) & & 4.775 & 3.855 & 4.219 & 2.631 & 6.244 \\
Inflation rate (\%) & 2.691 & 3.330 & 3.310 & -0.156 & 4.592 \\
Real interest rate (\%) & & & & & & \\
\hline
\end{tabular}

Table 5. Country- and year-wise contribution of efficient banks in the Sino-ASEAN frontier (in \%).

\begin{tabular}{ccccccccccccccc}
\hline & $\mathbf{2 0 0 0}$ & $\mathbf{2 0 0 1}$ & $\mathbf{2 0 0 2}$ & $\mathbf{2 0 0 3}$ & $\mathbf{2 0 0 4}$ & $\mathbf{2 0 0 5}$ & $\mathbf{2 0 0 6}$ & $\mathbf{2 0 0 7}$ & $\mathbf{2 0 0 8}$ & $\mathbf{2 0 0 9}$ & $\mathbf{2 0 1 0}$ & $\mathbf{2 0 1 1}$ & $\mathbf{2 0 1 2}$ & $\mathbf{2 0 1 3}$ \\
\hline China & 24 & 60 & 59 & 51 & 50 & 53 & 61 & 75 & 64 & 74 & 62 & 69 & 63 & 60 \\
Indonesia & 24 & 20 & 13 & 15 & 16 & 3 & 0 & 3 & 0 & 0 & 0 & 3 & 5 & 2 \\
Malaysia & 17 & 5 & 16 & 12 & 16 & 8 & 7 & 8 & 12 & 6 & 13 & 13 & 10 & 9 \\
Philippines & 0 & 5 & 0 & 0 & 6 & 3 & 2 & 0 & 2 & 0 & 2 & 0 & 3 & 2 \\
Singapore & 7 & 5 & 3 & 5 & 6 & 18 & 15 & 10 & 12 & 11 & 15 & 8 & 13 & 13 \\
Thailand & 14 & 0 & 6 & 10 & 0 & 13 & 2 & 3 & 7 & 0 & 2 & 3 & 0 & 0 \\
Vietnam & 14 & 5 & 3 & 7 & 6 & 5 & 12 & 3 & 2 & 9 & 6 & 5 & 8 & 13 \\
All & 100 & 100 & 100 & 100 & 100 & 100 & 100 & 100 & 100 & 100 & 100 & 100 & 100 & 100 \\
\hline
\end{tabular}

\subsection{Methods}

Following Banna et al. (2017), this study uses an input-oriented (cost minimization) approach of data envelopment analysis (DEA) to measure efficiency. In input-orientated models, the DEA method is used to classify technical inefficiency as a relative decline in input usage as well as to quantity technical inefficiency as a proportional increase in output or production. These two measures provide the same value under a constant return scale (CRS), but different values under a variable return scale (VRS). This has both theoretical and practical implications, for example, in businesses where the importance is placed on cost-control, the choice would be an input orientation (Ferrier and Valdmanis 1996). Besides, the choice of a VRS over a CRS is justified, such that all banks are not operating at an optimal scale due to imperfect competition and financial constraints (Barry et al. 2010).

A few issues have been raised by researchers while using non-parametric methods. However, the "two-step procedure" developed by Grosskopf (1996) and Lovell et al. (1995) is used to overcome this problem. This approach treats the efficiency score as regressand and the regression explains the variation of these efficiency scores. Casu and Molyneux (2003) argued that two-stage analysis is important, because in the first stage, only traditional inputs and outputs are involved, while in the second stage one can easily evaluate the direction, influence and strength of the relationship. They also claimed that a Tobit regression model (Tobin 1958) could be used, as it can explain the truncated data.

Another issue with using non-parametric methods is the dependency problem. The dependency problem exists because the DEA efficiency score is a relative and not absolute efficiency index (Xue and Harker 1999). To overcome this problem, the bootstrap method that was introduced by Efron (1979) is used. The advantages of the bootstrap method are that it gives an empirical distribution of efficiency scores for each observation in the sample (Atkinson and Wilson 1995) and that it evaluates the sensitivity of efficiency scores to the sampling deviations of the estimated frontier (Simar and Wilson 1998).

Although, we used bootstrapping Tobit regression in this study to minimize biased estimation and misspecification in the second stage. However, Simar and Wilson (2011) and Daraio et al. (2018) criticized the use of Tobit regression in the second stage, as it produces biased estimates and miss-specification. They argued that, in Tobit regression, explanatory variables are correlated with the disturbance term, hence the regression assumption of the disturbance term is independent of the explanatory variables and becomes invalid (separability issue). In this study, we also used a Simar and Wilson (2007) double bootstrap approach for the robustness of the study. 
The double bootstrap approach, in particular, helps to limit the problems arising both from the endogeneity of outreach measures, with respect to the efficiency of microfinance institutions (MFIs), and from the autocorrelation of the non-observable components of efficiency (Mia et al. 2018). This two-stage approach constitutes a methodological cornerstone in the literature for identifying the determinants of efficiency of financial institutions (Fukuyama and Matousek 2011). While using the Simar and Wilson (2007) bootstrapped procedure, we assumed that the "separability" assumption holds in the analysis.

\subsection{Input and Output Selection}

Although there is no inclusive theory for the banking firm and no agreement on the explicit definition and measurement of banks' inputs and outputs, Berger and Humphrey (1997) explained that an "intermediation approach" may be more suitable for assessing entire financial institutions, because of the inclusion of interest expenses, which typically account for one-half to two-thirds of total costs. Besides, the intermediation approach may be appropriate for assessing the significance of frontier efficiency to the profitability of financial institutions, since the minimization of total costs such as interest expenses, non-interest expenses and personnel expenses, not just production costs, is required to maximize profits. Following the previous studies (Banna et al. 2017; Casu and Molyneux 2003), the intermediation approach is used in financial institutions as intermediaries between the supply and demand of funds. The critical significance of the intermediation approach is to consider deposits as inputs and interest on deposits as an element of total costs. Therefore, we considered interest expenses, non-interest expenses, personnel expenses and deposits as inputs, whereas total loans, liquid assets and other earning assets were considered as outputs.

\subsection{Empirical Model Specification}

To calculate the efficiency score, this study used a two-step DEA approach, as proposed by Coelli et al. (1998) using the DEAP version 2.1 computer programming software to estimate the efficiency score ${ }^{2}$. The mathematical specification of the DEA-VRS input-oriented model is as follows:

$\operatorname{Min} \theta$

Such that:

$$
\begin{gathered}
\sum_{j=1}^{n} \varphi_{j} A_{i j} \leq \theta A_{i 0} ; i=1,2, \ldots . . x \\
\sum_{j=1}^{n} \varphi_{j} B_{q j} \leq B_{q 0} ; q=1,2, \ldots . y \\
\sum_{j=1}^{n} \varphi_{j}=1 \\
\varphi_{j} \geq 0 ; j \in 1,2 \ldots m
\end{gathered}
$$

where $\theta$ is the efficiency score, $A_{i j}$ and $B_{q j}$ are the amount of the $i$ th input consumed and the amount of the $q$ th output generated by the $j$ th bank, respectively. The index $m$ refers to the number of bank observations, $x$ equals the four inputs (interest expenses, non-interest expenses, personnel expenses and deposits) and $y$ refers to the three outputs (total loans, liquid assets and other earning assets) and $\varphi$ is constant.

Furthermore, in order to examine the determinants of Sino-ASEAN bank efficiency, we used the efficiency measures derived from the DEA estimations as the dependent variable using STATA version 15. We then estimated the following censored Tobit regression model for each of the sample countries.

$$
\begin{gathered}
\theta_{i j t}=\gamma_{0}+\gamma_{1} S_{I Z E_{i j t}}+\gamma_{2} \text { ROAA }_{i j t}+\gamma_{3} C A R_{i j t}+\gamma_{4} N_{I M} M_{i j t}+\gamma_{5} G D P_{j t}+\gamma_{6} I F_{j t} \\
+\gamma_{7} R_{j t}+\gamma_{8} \operatorname{DumCON}_{i}+\varepsilon_{i j t}
\end{gathered}
$$

2 We estimated numerous variations of Equation (1), including more and less aggregated inputs, combining the output measures and dropping individual inputs. The inferences of the study remain unchanged across the different DEA specifications. 
where:

$\theta_{i j t}=$ DEA efficiency score of the bank $i$ of country $j$ in year $t$;

$S I Z E_{i j t}=$ The natural logarithm of total assets of the bank $i$ of country $j$ in year $t$;

$R O A A_{i j t}=$ Return on average assets of the bank $i$ of country $j$ in year $t$;

$C A R_{i j t}=$ Capital adequacy ratio of the bank $i$ of country $j$ in year $t$;

$N I M_{i j t}=$ Net interest margin of the bank $i$ of country $j$ in year $t$;

$G D P_{j t}=$ Gross domestic product (GDP) growth of the country $i$ and in year $t$;

$I F_{j t}=$ Inflation rate of country $j$ in year $t$;

$R I_{j t}=$ Real interest rate of country $j$ and in year $t$;

$\operatorname{DumCON}_{i}$ is the country / ASEAN region dummy for indicating the country of origin (including China $(\mathrm{CH})$, Indonesia (ID), Malaysia (MY), the Philippines (PH), Singapore (SG), Thailand (TH), Vietnam $(\mathrm{VN})$ and ASEAN region) of the bank ( $1=$ if based in the country; $0=$ otherwise).

$\varepsilon_{i j t}=$ Error term of the bank $i$ of country $j$ in year $t$.

\section{Results and Discussion}

\subsection{Descriptive Statistics}

Table 3 provides the descriptive statistics on the inputs and outputs used in deriving DEA based efficiency scores for each bank in the region. Substantial differences were found in almost every variable across the sampled countries. We focused on two of them, the loans and the deposits, to compare the relative size of the banking sector of each country in the region. Specifically, we observed higher loans and deposits for China, followed by Singapore and Thailand, indicating the larger banking markets of these countries within the region. We also observed that Singapore, which comprises the smallest proportion of banks in our sample, had the second largest banking sector after China in the region in terms of loans and deposits. This indicates that Singapore has fewer but larger banks in this region. In contrast, Indonesia, with the second largest representation in the sample, has a relatively small size of loans and deposits, indicating the typical Indonesian banking market structure of many smaller banks.

The descriptive statistics of the variables applied in the regression analysis are produced in Table 4 . The table reports the mean, standard deviation, 25th, 50th (median) and 75th percentiles for each variable in the sample. A few observations from this table are noteworthy for the DEA scores. First, the efficiency scores for the region have a mean value of above 0.6 (mean $=0.637$, median $=0.63$ ), indicating the general tendency towards efficiency in the region. With these values, we infer that an average bank in the region suffers from about $36 \%$ (i.e., approximately $0.637-1$ ) of the inefficiencies during the period of study.

\subsection{DEA Efficiency Estimation}

Figure 1 depicts the country-wise mean efficiency scores for the whole period graphically. Generally, we observed a declining trend in efficiency scores over the period. Efficiency levels in the Sino-ASEAN region began to fall before the GFC, however, the pace after the crisis was faster. Specifically, the efficiency of Chinese banks seems to be declining, but at a decreasing rate. In contrast, except for Thailand and Singapore, the efficiency level of banks in the ASEAN follows a gradual decline over the period. Apart from a steep fall in efficiency in 2004, the banking sector efficiency of Thailand and Singapore is relatively stable, hovering around 0.7 . These observations imply the relative importance of location in determining banking sector efficiency during the sample period. We note that although the wave of the GFC was felt globally, its impact varied considerably between banking markets in different locations.

We summarize in Table 5 the contribution of efficient banks from each country in relative (percentage) terms in the Sino-ASEAN region. Our results show the dominance of Chinese banks in the formulation of the efficiency frontier. More specifically, in almost every year, Chinese banks make up more than half of the banks on the efficient frontier. This also indicates a relative immunity 
in the Chinese banking sector to the crisis. After China, Malaysian banks contribute most to the efficiency frontier, followed by Singapore. Results pertaining to Thailand and Philippines follow an almost similar pattern. Their contribution is noticeably lower in the post-crisis efficiency frontier. The contribution of the other banking markets seems relatively volatile.

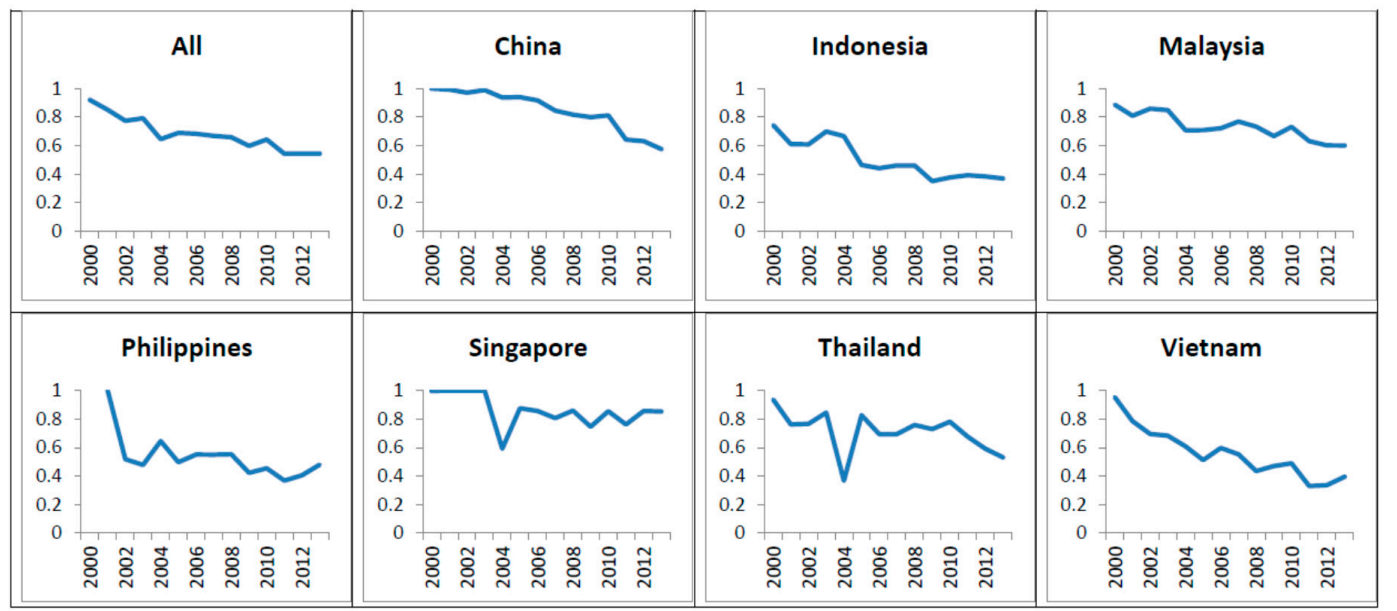

Figure 1. Country-year wise mean efficiency score. CN, ID, MY, PH, SG, TH and VN refer to China, Indonesia, Malaysia, Philippines, Singapore, Thailand and Vietnam, respectively.

Further, the period-wise breakup in Table 6 shows most of the efficient banks belong to China, followed by Indonesia and Malaysia, during the pre-crisis period. However, during the crisis period, the contribution of Indonesian banks declined significantly, while Malaysian and Chinese banks remained stable. During the crisis period, the share of Indonesian banks declined drastically to $1 \%$ from $13 \%$ in the pre-crisis period. The share of Singaporean banks on the other hand increased noticeably during the crisis period. We observe banks from Singapore have an increasing contribution to the efficiency frontier, especially during the crisis and post-crisis period. In short, our analysis indicates the highly stable contribution of Chinese banks in the efficiency frontier, regardless of the period. The share of Chinese banks rose above $70 \%$ during the crisis period, mainly owing to the decline of efficiency in other banking markets.

Table 6. Period-wise contribution of each country in the efficient frontier.

\begin{tabular}{ccccccccc}
\hline Year & China & Indonesia & Malaysia & Philippines & Singapore & Thailand & Vietnam & All \\
\hline 2000 & 0.24 & 0.24 & 0.17 & 0.00 & 0.07 & 0.14 & 0.14 & 1.00 \\
2001 & 0.60 & 0.20 & 0.05 & 0.05 & 0.05 & 0.00 & 0.05 & 1.00 \\
2002 & 0.59 & 0.13 & 0.16 & 0.00 & 0.03 & 0.06 & 0.03 & 1.00 \\
2003 & 0.51 & 0.15 & 0.12 & 0.00 & 0.05 & 0.10 & 0.07 & 1.00 \\
2004 & 0.50 & 0.16 & 0.16 & 0.06 & 0.06 & 0.00 & 0.06 & 1.00 \\
2005 & 0.53 & 0.03 & 0.08 & 0.03 & 0.18 & 0.13 & 0.05 & 1.00 \\
2006 & 0.61 & 0.00 & 0.07 & 0.02 & 0.15 & 0.02 & 0.12 & 1.00 \\
Pre-crisis overall & 0.51 & 0.13 & 0.12 & 0.02 & 0.08 & 0.06 & 0.07 & 1.00 \\
2007 & 0.75 & 0.03 & 0.08 & 0.00 & 0.10 & 0.03 & 0.03 & 1.00 \\
2008 & 0.64 & 0.00 & 0.12 & 0.02 & 0.12 & 0.07 & 0.02 & 1.00 \\
2009 & 0.74 & 0.00 & 0.06 & 0.00 & 0.11 & 0.00 & 0.09 & 1.00 \\
Crisis overall & 0.71 & 0.01 & 0.09 & 0.01 & 0.11 & 0.03 & 0.05 & 1.00 \\
2010 & 0.62 & 0.00 & 0.13 & 0.02 & 0.15 & 0.02 & 0.06 & 1.00 \\
2011 & 0.69 & 0.03 & 0.13 & 0.00 & 0.08 & 0.03 & 0.05 & 1.00 \\
2012 & 0.63 & 0.05 & 0.10 & 0.03 & 0.13 & 0.00 & 0.08 & 1.00 \\
2013 & 0.60 & 0.02 & 0.09 & 0.02 & 0.13 & 0.00 & 0.13 & 1.00 \\
Post-crisis overall & 0.64 & 0.03 & 0.11 & 0.02 & 0.12 & 0.01 & 0.08 & 1.00 \\
\hline
\end{tabular}

Table 7 summarizes the mean efficiency scores based on constant returns to scale (CRS) and variable returns to scale (VRS) for the three periods (i.e., pre-crisis, crisis and post-crisis) for the sampled countries. The Kruskal-Wallis (KW) test that was performed indicated significant differences between the mean 
scores for each period. The region was more efficient before the crisis period, whereas the lowest efficiency was observed during the post-crisis period, suggesting a slower pace of recovery after the GFC.

Table 7. DEA efficiency score in the different periods.

\begin{tabular}{|c|c|c|c|c|c|}
\hline \multirow[t]{2}{*}{ Period } & \multirow[t]{2}{*}{ Obs. } & \multicolumn{2}{|c|}{ CRS } & \multicolumn{2}{|c|}{ VRS } \\
\hline & & Mean & SD & Mean & SD \\
\hline Pre-crisis (2000-2006) & 874 & 0.570 & 0.255 & 0.733 & 0.243 \\
\hline Crisis (2007-2009) & 721 & 0.503 & 0.225 & 0.653 & 0.244 \\
\hline Post-crisis (2010-2013) & 1275 & 0.410 & 0.229 & 0.561 & 0.275 \\
\hline \multicolumn{6}{|c|}{ Kruskal-Wallis Test } \\
\hline $\mathrm{X}^{2}(\mathrm{df}=2)$ & & \multirow{2}{*}{\multicolumn{2}{|c|}{$\underset{* * *}{260.951}$}} & \multicolumn{2}{|c|}{217.140} \\
\hline Sig & & & & \multicolumn{2}{|c|}{$* * *$} \\
\hline
\end{tabular}

CRS: Constant return to scale, VRS: Variable return to scale SE: Scale efficiency (SE = CRS/VRS) ${ }^{* * *}$ Represent $1 \%$ significant level.

\subsection{Diagnostic Test}

In order to test for the integration and stationary properties of the variables used in this study, we applied the Fischer-augmented Dickey-Fuller (ADF) panel unit root test. The econometric literature offers a number of unit root tests, however, the Fischer-ADF root test is advantageous to use as it allows for maximum heterogeneity across units. Maddala and Wu (1999) applied non-parametric methods to conduct a Fischer-ADF unit root test. The test performs the null hypothesis that the series is non-stationary (or it has unit root). Table 8 summarizes the test statistics from the Fischer-ADF test in all versions, with and without trend and drift. The results indicate that the hypothesis of the unit root is rejected at a $1 \%$ level, in favor of stationarity.

Table 8. Unit root test of the variables.

\begin{tabular}{cccccccccc}
\hline & & Efficiency & Bank Size & ROAA & CAR & NIM & GDP Growth & Inflation & Real Interest \\
\hline Trend & chi2 & $1294.00^{*}$ & $918.86^{*}$ & 2001.28 & $1699.02^{*}$ & $1351.58^{*}$ & $1344.99^{*}$ & $1620.44^{*}$ & $1554.90^{*}$ \\
Drift & chi2 & $1787.84^{*}$ & $1253.71^{*}$ & $2181.22^{*}$ & $1735.76^{*}$ & $1821.95^{*}$ & $1956.16^{*}$ & $2449.30^{*}$ & $2359.75^{*}$ \\
None & chi2 & $1992.05^{*}$ & $1544.02^{*}$ & $2911.95^{*}$ & $2275.53^{*}$ & $1848.21^{*}$ & $1944.25^{*}$ & $2196.38^{*}$ & $2014.99^{*}$ \\
\hline * Significant at 1\% level of confidence. Fisher test for panel unit root using an augmented Dickey-Fuller test (0 lags).
\end{tabular}

Table 9 reports the univariate correlation between DEA efficiency scores and various determinants of bank efficiency. Correlation analysis is essential to understand the direction and strength of the two variables (Banna et al. 2018). It is also helpful as a pre-regression diagnosis for multicollinearity between the studied variables. The results show that most of our selected proxies for various firm characteristics are significantly correlated with the efficiency scores. However, none of them are too highly correlated to cause the multicollinearity problem. We found that size, profitability, capitalization and GDP had a positive correlation with bank efficiency, while interest, inflation and the net interest margin (NIM), on the other hand, had a negative correlation.

Table 9. Univariate correlation.

\begin{tabular}{|c|c|c|c|c|c|c|c|c|}
\hline & 1 & 2 & 3 & 4 & 5 & 6 & 7 & 8 \\
\hline Bank efficiency (1) & 1 & & & & & & & \\
\hline Bank size (2) & $0.2514 *$ & 1 & & & & & & \\
\hline ROAA (3) & 0.0307 & -0.0177 & 1 & & & & & \\
\hline CAR (4) & 0.0329 & $-0.5071 *$ & 0.1037 * & 1 & & & & \\
\hline NIM (5) & $-0.2276^{*}$ & $-0.2523 *$ & 0.1448 * & $0.2055 *$ & 1 & & & \\
\hline GDP (6) & 0.2985 * & $0.1945 *$ & -0.0334 & -0.1349 * & $-0.1335 *$ & 1 & & \\
\hline Inflation (7) & $-0.3526^{*}$ & $-0.2277^{*}$ & 0.0361 & 0.0189 & $0.1615 *$ & $-0.1831 *$ & 1 & \\
\hline Interest (8) & -0.0968 * & -0.0624 * & 0.0147 & 0.0657 * & 0.0583 * & $-0.3562 *$ & $-0.3151 *$ & 1 \\
\hline
\end{tabular}

* Significant at $1 \%$ level of confidence. 


\subsection{Regression Results}

Since efficiency scores are constrained between zero and one (Fried et al. 1993), we estimated the model through Tobit regression. Dougherty (2001) noted that ordinary least squares (OLS) yields biased estimates in this case. From Model 1-9, we calculate Equation (2) using the dummy for a specific country in each model to test if the geographical location effect is evidenced through the significance of the country's dummy coefficient (see Table 10). Model 8 uses an ASEAN dummy, holding China in the reference category. Finally, for an additional check of robustness, we ran a common model (Model 9) including all the country dummies for each country except China, which we held as a reference.

In each model, we controlled the commonly used bank-specific and country-specific determinants of efficiency to isolate the effect of the geographical location. The bank-specific variables included size (proxied by the natural log of assets), profitability measures such as ROAA and NIM and capitalization, measured as a capital ratio. The country-specific variables included GDP, inflation and the real interest rate. In bank-specific covariates, size and efficiency have a complex relationship, as some studies have found a positive relationship (Berger 1995; Hasan and Marton 2003), while others have observed negative relationship (Allen and Rai 1996; Kaparakis et al. 1994). The empirical relationship between profitability and efficiency is also unclear, although, profitability should positively affect efficiency (Berger 1995). Some studies (such as Altunbas et al. 2000 among others) have found a negative relationship profitability and efficiency.

Capitalization may influence bank performance in either direction. A low capital ratio magnifies risk, which may lead to an inverse relationship between capitalization and efficiency, as more efficient banks can afford to take greater risks (Berger 1995). However, an argument can also be made in favor of a positive relationship, as a lower capitalization ratio might decrease the bank's cost of capital (Molyneux 1993) and expected costs of financial distress (Berger 1995). Previous studies generally support a positive relationship (Berger 1995; Demirgüç-Kunt and Huizinga 1999; Goddard et al. 2004 among others). Bank efficiency may also be sensitive to changes in macroeconomic conditions. Therefore, we use GDP to control for economic development and inflation to control for economic stability. Growth might lead to an overall increase in banking sector efficiency, resulting in a direct relationship between GDP and efficiency. Inflation may affect bank efficiency through the channel of the real value of banking sector costs and revenue (Perry 1992).

Table 10 displays the Tobit regression results for the geographical location effect and other control variables. Model 1 (as given in Equation (2)) tests the country effect of China, using the dummy for China. Applying a similar procedure, we run the regressions for each of the other six countries in the sample (Model 2-7) and the ASEAN countries (Model 8). Turning to the results, we first noticed that all of the country dummies returned significantly in Models 1-8, which suggests evidence of the geographical location effect during the period of analysis. For a further check of robustness, Model 9 employs all the country dummies in a single model and tests our first hypotheses by determining whether the coefficients of the country dummies were significant individually $\left(\mathrm{H0}: \gamma_{8-14}=0\right)$ and Equation (2) determines whether they differed significantly from each other $\left(\mathrm{H}_{0}: \gamma_{8}=\gamma_{9}=\gamma_{10}=\right.$ $\left.\gamma_{11}=\gamma_{12}=\gamma_{13}=\gamma_{14}\right)$. We held China as a reference to avoid the dummy variable trap. The results of the Wald test suggest a rejection of the null hypothesis of equality of intercepts of the banking markets under study. Therefore, our results bolster the hypothesis that the location or banking market has an important and significant role in explaining banking sector efficiency in the Sino-ASEAN region.

Among the bank-specific factors, size, profitability and capitalization returned as positive and highly significant $(p<0.01)$, with highly stable estimates across all the models applied in our study, supporting the findings of Mester (1996), Lozano-Vivas et al. (2002) and Carbo et al. (2003). Turning to the country level determinants, we observed the significant positive impact of the country's growth on bank efficiency. This suggests that countries experiencing higher growth also had a more efficient banking sector during the period of study. Our result is consistent with Grigorian and Manole (2006). Both inflation and real interest, on the other hand, returned a negative coefficient in the regression. 
As expected, this confirms the detrimental effect of economic instability on the efficiency of the banking sector. Our results thus support Tajgardoon et al. (2012).

We extended our analysis of the location effect on banking sector efficiency by including the effect of the global financial crisis (see Tables 11-13). In order to achieve this objective, we divided our sample into three sub-periods (pre-crisis, 2000-2006; crisis, 2007-2009; post-crisis, 2010-2013) and performed the regression analysis for each period. The significantly positive country dummy coefficients in our model suggested that during the pre-crisis period, banks belonging to China and Indonesia were more likely to be efficient due to the geographical location effect. No other country dummy returned as positive, suggesting that banks in these nations experienced relatively low efficiency during this period, which could be attributed to the geographical location effect.

The results during the crisis period further bolster the evidence of the geographical location effect on the efficiency scores of banks. We observed that unlike in the pre-crisis period, the Indonesian dummy returned as negative and significant, whereas Malaysia returned as significantly positive. These results suggest that Indonesian banks were no longer able to capitalize on the positive effect as they had before. We found the same tendency among Chinese banks in the crisis period as in the period before the crisis. Finally, evidence for geographical location effect was also found when we found a significantly negative coefficient for the Chinese dummy, which was consistently positive during the previous periods. The decline in banking performance, especially the efficiency of the banks in China, may be due to non-performing loans and special mention loans (Jiang et al. 2007). On the other hand, Singapore and Thailand returned as significantly positive in the model, which were showing a negative effect during the earlier periods. The changing signs of the country dummies were statistically significant during the different periods of our location effect analysis, clearly indicating the importance of the geographical location effect in terms of banking sector efficiency in the Sino-ASEAN region.

\subsection{Robustness Check}

The results presented and discussed so far need to be interpreted with caution, due to the violation of independence within the sample, which is one of the fundamental assumptions of the regression method. The problem of dependency within the sample stems from the inherently dependent nature of the efficiency score. To overcome this limitation we applied a bootstrapping technique, as described by Xue and Harker (1999).

To implement the bootstrapping technique, we first created the sample probability distribution $\hat{F}$ and assigned each decision-making unit (DMU) a probability of $1 / n^{3}$. We then created 1000 random bootstrap samples, each with 220 banks from the observed sample of 220 banks in the Sino-ASEAN region, and computed the DEA based efficiency scores for each bootstrap sample. For each bootstrap sample, we fit the following regression equation and estimated the standard error $\widehat{s e}_{c}\left(\hat{\beta}_{j}\right)$ by the sample standard deviation of the 1000 bootstrap replications of $\left(\hat{\beta}_{j}\right)$. Finally, we applied the traditional t-test to test the hypothesis of $\beta_{j}=0$ against $\beta_{j} \neq 0$ at a conventional $5 \%$ level.

The estimates from the bootstrapping procedure are summarized in Table 14. The results of bootstrap regression are fairly similar to our earlier findings. The $\mathrm{F}$ test signifies the rejection of the null hypothesis that the intercepts for the seven banking systems are equal. Likewise, all the results for the control variables were similar to our previous Tobit regression.

As Simar and Wilson $(2007,2011)$ criticized the Tobit regression model because of biased estimations, misspecification and separability issues. Based on their suggestion, we also ran the Simar and Wilson (2007) double bootstrapped truncated regression model, using 2000 replications in the second stage holding separability assumption. The double bootstrapping results are presented in Table 15.

3 To complete this exercise, the balanced sample on a pooled Sino-ASEAN basis (220 observations) was considered. 
Table 10. Determinants of bank efficiency (Tobit regression) with the geographical location effect.

\begin{tabular}{|c|c|c|c|c|c|c|c|c|c|c|}
\hline & Exp. Sign & Model 1 & Model 2 & Model 3 & Model 4 & Model 5 & Model 6 & Model 7 & Model 8 & Model 9 \\
\hline Size & $+/-$ & $\begin{array}{c}0.031^{* * * *} \\
(0.003)\end{array}$ & $\begin{array}{c}0.032^{* * * *} \\
(0.003)\end{array}$ & $\begin{array}{c}0.034^{* * * *} \\
(0.003)\end{array}$ & $\begin{array}{c}0.032 * * * \\
(0.003)\end{array}$ & $\begin{array}{c}0.032 * * * \\
(0.003)\end{array}$ & $\begin{array}{c}0.033^{* * * *} \\
(0.003)\end{array}$ & $\begin{array}{c}0.033^{* * * *} \\
(0.003)\end{array}$ & $\begin{array}{c}0.031^{* * * *} \\
(0.003)\end{array}$ & $\begin{array}{c}0.021^{* * * *} \\
(0.003)\end{array}$ \\
\hline ROAA & + & $\begin{array}{c}0.008^{* * *} \\
(0.003)\end{array}$ & $\begin{array}{c}0.008^{* * *} \\
(0.003)\end{array}$ & $\begin{array}{c}0.007^{* * * *} \\
(0.003)\end{array}$ & $\begin{array}{c}0.007^{* * *} \\
(0.002)\end{array}$ & $\begin{array}{c}0.007^{* * *} \\
(0.003)\end{array}$ & $\begin{array}{c}0.008 \\
(0.003)\end{array}$ & $\begin{array}{c}0.008^{* * *} \\
(0.003)\end{array}$ & $\begin{array}{c}0.008^{* * *} \\
(0.003)\end{array}$ & $\begin{array}{c}0.008^{* * *} \\
(0.003)\end{array}$ \\
\hline CAR & + & $\begin{array}{c}0.006^{* * *} \\
(0.001)\end{array}$ & $\begin{array}{c}0.006^{* * *} \\
(0.001)\end{array}$ & $\begin{array}{c}0.006^{* * * *} \\
(0.001)\end{array}$ & $\begin{array}{c}0.006^{* * *} \\
(0.001)\end{array}$ & $\begin{array}{c}0.006^{* * * *} \\
(0.001)\end{array}$ & $\begin{array}{c}0.006^{* * *} \\
(0.001)\end{array}$ & $\begin{array}{c}0.007^{* * *} \\
(0.001)\end{array}$ & $\begin{array}{c}0.006^{* * *} \\
(0.001)\end{array}$ & $\begin{array}{c}0.005^{* * *} \\
(0.001)\end{array}$ \\
\hline NIM & $+/-$ & $\begin{array}{c}-0.016^{* * *} \\
(0.002)\end{array}$ & $\begin{array}{c}-0.016^{* * *} \\
(0.002)\end{array}$ & $\begin{array}{c}-0.016^{* * *} \\
(0.002)\end{array}$ & $\begin{array}{c}-0.015^{* * *} \\
(0.002)\end{array}$ & $\begin{array}{c}-0.015^{* * * *} \\
(0.002)\end{array}$ & $\begin{array}{c}-0.016^{* * *} \\
(0.002)\end{array}$ & $\begin{array}{c}-0.018^{* * * *} \\
(0.002)\end{array}$ & $\begin{array}{c}-0.016^{* * *} \\
(0.002)\end{array}$ & $\begin{array}{c}-0.012^{* * * *} \\
(0.002)\end{array}$ \\
\hline GDP & + & $\begin{array}{c}0.016^{* * * *} \\
(0.003)\end{array}$ & $\begin{array}{c}0.021^{* * *} \\
(0.002)\end{array}$ & $\begin{array}{c}0.023^{* * * *} \\
(0.002)\end{array}$ & $\begin{array}{c}0.019^{* * *} \\
(0.002)\end{array}$ & $\begin{array}{c}0.022 * * * \\
(0.002)\end{array}$ & $\begin{array}{c}0.022^{* * * *} \\
(0.002)\end{array}$ & $\begin{array}{c}0.021^{* * * *} \\
(0.002)\end{array}$ & $\begin{array}{c}0.016^{* * * *} \\
(0.003)\end{array}$ & $\begin{array}{c}0.019 * * * \\
(0.003)\end{array}$ \\
\hline IF & - & $\begin{array}{c}-0.021^{* * *} \\
(0.002)\end{array}$ & $\begin{array}{c}-0.021^{* * *} \\
(0.002)\end{array}$ & $\begin{array}{c}-0.021^{* * *} \\
(0.002)\end{array}$ & $\begin{array}{c}-0.023^{* * *} \\
(0.002)\end{array}$ & $\begin{array}{c}-0.022^{* * *} \\
(0.002)\end{array}$ & $\begin{array}{c}-0.022^{* * *} \\
(0.002)\end{array}$ & $\begin{array}{c}-0.020^{* * *} \\
(0.002)\end{array}$ & $\begin{array}{c}-0.021^{* * * *} \\
(0.002)\end{array}$ & $\begin{array}{c}-0.011^{* * *} \\
(0.002)\end{array}$ \\
\hline RI & - & $\begin{array}{c}-0.010^{* * * *} \\
(0.002)\end{array}$ & $\begin{array}{c}-0.009^{* * *} \\
(0.002)\end{array}$ & $\begin{array}{c}-0.009^{* * *} \\
(0.002)\end{array}$ & $\begin{array}{c}-0.010^{* * *} \\
(0.002)\end{array}$ & $\begin{array}{c}-0.010^{* * * *} \\
(0.002)\end{array}$ & $\begin{array}{c}-0.010^{* * *} \\
(0.002)\end{array}$ & $\begin{array}{c}-0.010^{* * * *} \\
(0.002)\end{array}$ & $\begin{array}{c}-0.010^{* * *} \\
(0.002)\end{array}$ & $\begin{array}{c}-0.005^{* *} \\
(0.002)\end{array}$ \\
\hline $\mathrm{CN}$ & & $\begin{array}{c}0.050^{* * * *} \\
(0.017)\end{array}$ & & & & & & & & \\
\hline ID & & & $\begin{array}{c}-0.034^{* *} \\
(0.015)\end{array}$ & & & & & & & $\begin{array}{c}-0.133 * * * \\
(0.022)\end{array}$ \\
\hline MY & & & & $\begin{array}{c}0.054^{* * *} \\
(0.019)\end{array}$ & & & & & & $\begin{array}{c}0.015 \\
(0.023)\end{array}$ \\
\hline PH & & & & & $\begin{array}{c}-0.106^{* * *} \\
(0.020)\end{array}$ & & & & & $\begin{array}{c}-0.170^{* * * *} \\
(0.024)\end{array}$ \\
\hline SG & & & & & & $\begin{array}{c}0.182^{* * *} \\
(0.029)\end{array}$ & & & & $\begin{array}{c}0.144^{* * *} \\
(0.031)\end{array}$ \\
\hline TH & & & & & & & $\begin{array}{l}0.038^{*} \\
(0.020)\end{array}$ & & & $\begin{array}{l}-0.001 \\
(0.024)\end{array}$ \\
\hline VN & & & & & & & & $\begin{array}{c}-0.070^{* * *} \\
(0.018)\end{array}$ & & $\begin{array}{c}-0.161^{* * * *} \\
(0.024)\end{array}$ \\
\hline ASEAN & & & & & & & & & $\begin{array}{c}-0.050^{* * *} \\
(0.017)\end{array}$ & \\
\hline Time trend & & $\begin{array}{c}-0.042^{* * *} \\
(0.001)\end{array}$ & $\begin{array}{c}-0.040^{* * *} \\
(0.001)\end{array}$ & $\begin{array}{c}-0.039 * * * \\
(0.001)\end{array}$ & $\begin{array}{c}-0.039 * * * \\
(0.001)\end{array}$ & $\begin{array}{c}-0.039 * * * \\
(0.001)\end{array}$ & $\begin{array}{c}-0.040^{* * *} \\
(0.001)\end{array}$ & $\begin{array}{c}-0.039 * * * \\
(0.001)\end{array}$ & $\begin{array}{c}-0.041^{* * *} \\
(0.001)\end{array}$ & $\begin{array}{c}-0.041^{* * * *} \\
(0.001)\end{array}$ \\
\hline Constant & & $\begin{array}{c}0.389^{* * * *} \\
(0.040)\end{array}$ & $\begin{array}{c}0.371^{* * *} \\
(0.039)\end{array}$ & $\begin{array}{c}0.324^{* * * *} \\
(0.040)\end{array}$ & $\begin{array}{c}0.383^{* * * *} \\
(0.039)\end{array}$ & $\begin{array}{c}0.354^{* * *} \\
(0.039)\end{array}$ & $\begin{array}{c}0.348^{* * * *} \\
(0.039)\end{array}$ & $\begin{array}{c}0.364^{* * * *} \\
(0.039)\end{array}$ & $\begin{array}{c}0.439^{* * * *} \\
(0.048)\end{array}$ & $\begin{array}{c}0.452^{* * *} \\
(0.047)\end{array}$ \\
\hline
\end{tabular}


Table 10. Cont.

\begin{tabular}{|c|c|c|c|c|c|c|c|c|c|c|}
\hline & Exp. Sign & Model 1 & Model 2 & Model 3 & Model 4 & Model 5 & Model 6 & Model 7 & Model 8 & Model 9 \\
\hline Pseudo $\mathbf{R}^{2}$ & & 0.3571 & 0.3558 & 0.3569 & 0.3652 & 0.3698 & 0.3551 & 0.3596 & 0.3571 & 0.4088 \\
\hline Adjusted $R^{2}$ (OLS) & & 0.2606 & 0.2602 & 0.2608 & 0.2665 & 0.2653 & 0.2610 & 0.2630 & 0.2606 & 0.2956 \\
\hline LR chi2 & & 869.07 & 865.76 & 868.61 & 888.81 & 899.99 & 864.13 & 875.15 & 869.07 & 994.96 \\
\hline Prob > chi2 & & 0.00 & 0.00 & 0.00 & 0.00 & 0.00 & 0.00 & 0.00 & 0.00 & 0.00 \\
\hline Log likelihood & & -782.25 & -783.91 & -782.48 & -772.38 & -766.79 & -784.72 & -779.21 & -782.25 & -719.31 \\
\hline Obs. & & 2870 & 2870 & 2870 & 2870 & 2870 & 2870 & 2870 & 2870 & 2870 \\
\hline
\end{tabular}

Dependent variable $=$ DEA score, ${ }^{* * *}, * *$, and ${ }^{*}$ represent significance at $1 \%, 5 \%$ and $10 \%$ levels of confidence. ROAA, CAR, NIM, IF, RI, CN, ID, MY, PH, SG, TH and VN refer to return on average assets, capital adequacy ratio, net interest margin, inflation, real interest rate, China, Indonesia, Malaysia, the Philippines, Singapore, Thailand and Vietnam, respectively. All other variables are defined in Table 1.

Table 11. Determinants of bank efficiency (Tobit regression) pre-crisis.

\begin{tabular}{|c|c|c|c|c|c|c|c|c|c|c|}
\hline & Exp. Sign & Model 1 & Model 2 & Model 3 & Model 4 & Model 5 & Model 6 & Model 7 & Model 8 & Model 9 \\
\hline Size & $+1-$ & $\begin{array}{c}0.038^{* * *} \\
(0.005)\end{array}$ & $\begin{array}{c}0.044^{* * *} \\
(0.005)\end{array}$ & $\begin{array}{c}0.038^{* * *} \\
(0.005)\end{array}$ & $\begin{array}{c}0.037 * * * \\
(0.005)\end{array}$ & $\begin{array}{c}0.038^{* * *} \\
(0.005)\end{array}$ & $\begin{array}{c}0.046^{* * *} \\
(0.006)\end{array}$ & $\begin{array}{c}0.035^{* * *} \\
(0.005)\end{array}$ & $\begin{array}{c}0.038^{* * *} \\
(0.005)\end{array}$ & $\begin{array}{c}0.046^{* * *} \\
(0.005)\end{array}$ \\
\hline ROAA & + & $\begin{array}{c}0.012^{* * * *} \\
(0.004)\end{array}$ & $\begin{array}{c}0.006 \\
(0.004)\end{array}$ & $\begin{array}{l}0.008^{*} \\
(0.005)\end{array}$ & $\begin{array}{c}0.006 \\
(0.003)\end{array}$ & $\begin{array}{l}0.009 * \\
(0.005)\end{array}$ & $\begin{array}{c}0.007 \\
(0.005)\end{array}$ & $\begin{array}{l}0.009 * * \\
(0.005)\end{array}$ & $\begin{array}{c}0.012^{* * * *} \\
(0.004)\end{array}$ & $\begin{array}{c}0.006 \\
(0.004)\end{array}$ \\
\hline CAR & + & $\begin{array}{c}0.008^{* * *} \\
(0.001)\end{array}$ & $\begin{array}{c}0.008^{* * *} \\
(0.001)\end{array}$ & $\begin{array}{c}0.007^{* * * *} \\
(0.001)\end{array}$ & $\begin{array}{c}0.007^{* * *} \\
(0.001)\end{array}$ & $\begin{array}{c}0.007^{* * *} \\
(0.001)\end{array}$ & $\begin{array}{c}0.008^{* * *} \\
(0.001)\end{array}$ & $\begin{array}{c}0.007^{* * *} \\
(0.001)\end{array}$ & $\begin{array}{c}0.008^{* * *} \\
(0.001)\end{array}$ & $\begin{array}{c}0.009^{* * *} \\
(0.001)\end{array}$ \\
\hline NIM & $+/-$ & $\begin{array}{c}-0.019^{* * *} \\
(0.004)\end{array}$ & $\begin{array}{c}-0.023^{* * *} \\
(0.004)\end{array}$ & $\begin{array}{c}-0.019^{* * *} \\
(0.004)\end{array}$ & $\begin{array}{c}-0.017^{* * *} \\
(0.004)\end{array}$ & $\begin{array}{c}-0.020^{* * *} \\
(0.004)\end{array}$ & $\begin{array}{c}-0.020^{* * *} \\
(0.004)\end{array}$ & $\begin{array}{c}-0.020^{* * *} \\
(0.004)\end{array}$ & $\begin{array}{c}-0.019^{* * *} \\
(0.004)\end{array}$ & $\begin{array}{c}-0.018^{* * *} \\
(0.004)\end{array}$ \\
\hline GDP & + & $\begin{array}{c}-0.021 * * * \\
(0.006)\end{array}$ & $\begin{array}{c}0.031^{* * *} \\
(0.004)\end{array}$ & $\begin{array}{c}0.027^{* * *} \\
(0.004)\end{array}$ & $\begin{array}{c}0.025^{* * *} \\
(0.004)\end{array}$ & $\begin{array}{c}0.028^{* * *} \\
(0.004)\end{array}$ & $\begin{array}{c}0.021 * * * \\
(0.004)\end{array}$ & $\begin{array}{c}0.028^{* * *} \\
(0.004)\end{array}$ & $\begin{array}{c}-0.021^{* * *} \\
(0.006)\end{array}$ & $\begin{array}{c}-0.025^{* * *} \\
(0.006)\end{array}$ \\
\hline IF & - & $\begin{array}{c}-0.023^{* * *} \\
(0.002)\end{array}$ & $\begin{array}{c}-0.039^{* * *} \\
(0.003)\end{array}$ & $\begin{array}{c}-0.027^{* * *} \\
(0.003)\end{array}$ & $\begin{array}{c}-0.028^{* * *} \\
(0.002)\end{array}$ & $\begin{array}{c}-0.027^{* * *} \\
(0.002)\end{array}$ & $\begin{array}{c}-0.030^{* * *} \\
(0.003)\end{array}$ & $\begin{array}{c}-0.027^{* * *} \\
(0.002)\end{array}$ & $\begin{array}{c}-0.023^{* * *} \\
(0.002)\end{array}$ & $\begin{array}{c}-0.031 \\
(0.003)\end{array}$ \\
\hline RI & - & $\begin{array}{l}0.004^{*} \\
(0.002)\end{array}$ & $\begin{array}{c}0.008^{* * *} \\
(0.003)\end{array}$ & $\begin{array}{c}0.010^{* * *} \\
(0.003)\end{array}$ & $\begin{array}{c}0.010^{* * *} \\
(0.003)\end{array}$ & $\begin{array}{c}0.010^{* * *} \\
(0.003)\end{array}$ & $\begin{array}{c}0.010^{* * *} \\
(0.003)\end{array}$ & $\begin{array}{c}0.009^{* * *} \\
(0.003)\end{array}$ & $\begin{array}{l}0.004 * \\
(0.002)\end{array}$ & $\begin{array}{l}0.004 \text { * } \\
(0.002)\end{array}$ \\
\hline $\mathrm{CN}$ & & $\begin{array}{c}0.394^{* * *} \\
(0.038)\end{array}$ & & & & & & & & \\
\hline ID & & & $\begin{array}{c}0.169 * * * \\
(0.028)\end{array}$ & & & & & & & $\begin{array}{c}-0.311^{* * *} \\
(0.052)\end{array}$ \\
\hline MY & & & & $\begin{array}{l}-0.002 \\
(0.028)\end{array}$ & & & & & & $\begin{array}{c}-0.376^{* * *} \\
(0.045)\end{array}$ \\
\hline PH & & & & & $\begin{array}{c}-0.181^{* * *} \\
(0.030)\end{array}$ & & & & & $\begin{array}{c}-0.519 * * * \\
(0.050)\end{array}$ \\
\hline
\end{tabular}


Table 11. Cont.

\begin{tabular}{|c|c|c|c|c|c|c|c|c|c|c|}
\hline & Exp. Sign & Model 1 & Model 2 & Model 3 & Model 4 & Model 5 & Model 6 & Model 7 & Model 8 & Model 9 \\
\hline SG & & & & & & $\begin{array}{l}-0.036 \\
(0.049)\end{array}$ & & & & $\begin{array}{c}-0.306^{* * *} \\
(0.051)\end{array}$ \\
\hline TH & & & & & & & $\begin{array}{c}-0.145^{* * *} \\
(0.029)\end{array}$ & & & $\begin{array}{c}-0.489 \text { *** } \\
(0.047)\end{array}$ \\
\hline VN & & & & & & & & $\begin{array}{l}-0.079 \\
(0.029)\end{array}$ & & $\begin{array}{c}-0.350^{* * *} \\
(0.044)\end{array}$ \\
\hline ASEAN & & & & & & & & & $\begin{array}{c}-0.394^{* * *} \\
(0.038)\end{array}$ & \\
\hline Time trend & & $\begin{array}{c}-0.038^{* * *} \\
(0.005)\end{array}$ & $\begin{array}{c}-0.042 * * * \\
(0.005)\end{array}$ & $\begin{array}{c}-0.048^{* * *} \\
(0.005)\end{array}$ & $\begin{array}{c}-0.042^{* * *} \\
(0.005)\end{array}$ & $\begin{array}{c}-0.047^{* * *} \\
(0.005)\end{array}$ & $\begin{array}{c}-0.045^{* * *} \\
(0.005)\end{array}$ & $\begin{array}{c}-0.047^{* * *} \\
(0.005)\end{array}$ & $\begin{array}{c}-0.038^{* * *} \\
(0.005)\end{array}$ & $\begin{array}{c}-0.031 \text { *** } \\
(0.005)\end{array}$ \\
\hline Constant & & $\begin{array}{c}0.611^{* * *} \\
(0.060)\end{array}$ & $\begin{array}{c}0.333^{* * *} \\
(0.059)\end{array}$ & $\begin{array}{c}0.390 * * * \\
(0.062)\end{array}$ & $\begin{array}{c}0.422 * * * \\
(0.058)\end{array}$ & $\begin{array}{c}0.387^{* * *} \\
(0.060)\end{array}$ & $\begin{array}{c}0.408^{* * *} \\
(0.059)\end{array}$ & $\begin{array}{c}0.418^{* * *} \\
(0.060)\end{array}$ & $\begin{array}{c}1.005^{* * *} \\
(0.081)\end{array}$ & $\begin{array}{c}0.988^{* * *} \\
(0.085)\end{array}$ \\
\hline Pseudo $\mathbf{R}^{2}$ & & 0.7052 & 0.6194 & 0.5726 & 0.6164 & 0.5733 & 0.6040 & 0.5820 & 0.7052 & 0.7812 \\
\hline Adjusted $R^{2}$ & & 0.4502 & 0.4253 & 0.4021 & 0.4301 & 0.4032 & 0.4123 & 0.4066 & 0.4502 & 0.4825 \\
\hline LR chi2 & & 556.06 & 488.39 & 451.51 & 486.06 & 452.05 & 476.27 & 458.94 & 556.06 & 615.95 \\
\hline Prob > chi2 & & 0.00 & 0.00 & 0.00 & 0.00 & 0.00 & 0.00 & 0.00 & 0.00 & 0.00 \\
\hline Log likelihood & & -116.22 & -150.06 & -168.50 & -151.22 & -168.23 & -156.12 & -164.78 & -116.22 & -86.28 \\
\hline Obs. & & 874 & 874 & 874 & 874 & 874 & 874 & 874 & 874 & 874 \\
\hline
\end{tabular}

Dependent variable $=$ DEA score, ${ }^{* * *}, * *$, and ${ }^{*}$ represent significance at $1 \%, 5 \%$ and $10 \%$ levels of confidence. ROAA, CAR, NIM, IF, RI, CN, ID, MY, PH, SG, TH and VN refer to return on average assets, capital adequacy ratio, net interest margin, inflation, real interest rate, China, Indonesia, Malaysia, the Philippines, Singapore, Thailand and Vietnam, respectively. All other variables are defined in Table 1 .

Table 12. Determinants of bank efficiency (Tobit regression) during the crisis.

\begin{tabular}{|c|c|c|c|c|c|c|c|c|c|c|}
\hline & Exp. Sign & Model 1 & Model 2 & Model 3 & Model 4 & Model 5 & Model 6 & Model 7 & Model 8 & Model 9 \\
\hline Size & $+/-$ & $\begin{array}{c}0.073^{* * *} \\
(0.005)\end{array}$ & $\begin{array}{c}0.070^{* * *} \\
(0.005)\end{array}$ & $\begin{array}{c}0.080 * * * \\
(0.005)\end{array}$ & $\begin{array}{c}0.079 * * * \\
(0.005)\end{array}$ & $\begin{array}{c}0.078^{* * *} \\
(0.005)\end{array}$ & $\begin{array}{c}0.078^{* * *} \\
(0.005)\end{array}$ & $\begin{array}{c}0.079 * * * \\
(0.005)\end{array}$ & $\begin{array}{c}0.073^{* * *} \\
(0.005)\end{array}$ & $\begin{array}{c}0.061^{* * *} \\
(0.005)\end{array}$ \\
\hline ROAA & + & $\begin{array}{l}-0.000 \\
(0.003)\end{array}$ & $\begin{array}{l}-0.002 \\
(0.002)\end{array}$ & $\begin{array}{l}-0.001 \\
(0.003)\end{array}$ & $\begin{array}{l}-0.001 \\
(0.003)\end{array}$ & $\begin{array}{l}-0.001 \\
(0.003)\end{array}$ & $\begin{array}{l}-0.000 \\
(0.003)\end{array}$ & $\begin{array}{l}-0.000 \\
(0.003)\end{array}$ & $\begin{array}{l}-0.000 \\
(0.003)\end{array}$ & $\begin{array}{l}-0.001 \\
(0.002)\end{array}$ \\
\hline CAR & + & $\begin{array}{c}0.012^{* * *} \\
(0.001)\end{array}$ & $\begin{array}{c}0.011^{* * *} \\
(0.001)\end{array}$ & $\begin{array}{c}0.012 \text { *** } \\
(0.001)\end{array}$ & $\begin{array}{c}0.012 * * * \\
(0.001)\end{array}$ & $\begin{array}{c}0.012 * * * \\
(0.001)\end{array}$ & $\begin{array}{c}0.012^{* * *} \\
(0.001)\end{array}$ & $\begin{array}{c}0.012^{* * *} \\
(0.001)\end{array}$ & $\begin{array}{c}0.012^{* * *} \\
(0.001)\end{array}$ & $\begin{array}{c}0.010^{* * *} \\
(0.001)\end{array}$ \\
\hline NIM & $+/-$ & $\begin{array}{c}-0.010^{* * *} \\
(0.003)\end{array}$ & $\begin{array}{l}-0.004 \\
(0.003)\end{array}$ & $\begin{array}{c}-0.010 \text { *** } \\
(0.003)\end{array}$ & $\begin{array}{c}-0.011^{* * *} \\
(0.003)\end{array}$ & $\begin{array}{c}-0.011 \text { *** } \\
(0.003)\end{array}$ & $\begin{array}{c}-0.012^{* * *} \\
(0.003)\end{array}$ & $\begin{array}{c}-0.012^{* * *} \\
(0.003)\end{array}$ & $\begin{array}{c}-0.010 \text { *** } \\
(0.003)\end{array}$ & $\begin{array}{l}-0.002 \\
(0.003)\end{array}$ \\
\hline GDP & + & $\begin{array}{c}0.003 \\
(0.003)\end{array}$ & $\begin{array}{c}0.016^{* * *} \\
(0.002)\end{array}$ & $\begin{array}{c}0.021^{* * *} \\
(0.002)\end{array}$ & $\begin{array}{c}0.017^{* * *} \\
(0.002)\end{array}$ & $\begin{array}{c}0.019^{* * *} \\
(0.002)\end{array}$ & $\begin{array}{c}0.019^{* * *} \\
(0.002)\end{array}$ & $\begin{array}{c}0.018^{* * *} \\
(0.002)\end{array}$ & $\begin{array}{c}0.003 \\
(0.003)\end{array}$ & $\begin{array}{c}0.013^{* * *} \\
(0.003)\end{array}$ \\
\hline
\end{tabular}


Table 12. Cont.

\begin{tabular}{|c|c|c|c|c|c|c|c|c|c|c|}
\hline & Exp. Sign & Model 1 & Model 2 & Model 3 & Model 4 & Model 5 & Model 6 & Model 7 & Model 8 & Model 9 \\
\hline IF & - & $\begin{array}{c}-0.016^{* * *} \\
(0.002)\end{array}$ & $\begin{array}{c}-0.020^{* * *} \\
(0.002)\end{array}$ & $\begin{array}{c}-0.019^{* * *} \\
(0.002)\end{array}$ & $\begin{array}{c}-0.021^{* * *} \\
(0.002)\end{array}$ & $\begin{array}{c}-0.020^{* * *} \\
(0.002)\end{array}$ & $\begin{array}{c}-0.020^{* * *} \\
(0.002)\end{array}$ & $\begin{array}{c}-0.020^{* * *} \\
(0.003)\end{array}$ & $\begin{array}{c}-0.016^{* * *} \\
(0.002)\end{array}$ & $\begin{array}{c}-0.006^{* *} \\
(0.003)\end{array}$ \\
\hline RI & - & $\begin{array}{c}-0.018^{* * *} \\
(0.003)\end{array}$ & $\begin{array}{c}-0.018^{* * *} \\
(0.003)\end{array}$ & $\begin{array}{c}-0.017^{* * *} \\
(0.003)\end{array}$ & $\begin{array}{c}-0.019 \text { *** } \\
(0.003)\end{array}$ & $\begin{array}{c}-0.018^{* * *} \\
(0.003)\end{array}$ & $\begin{array}{c}-0.018^{* * *} \\
(0.003)\end{array}$ & $\begin{array}{c}-0.018^{* * *} \\
(0.003)\end{array}$ & $\begin{array}{c}-0.018^{* * *} \\
(0.003)\end{array}$ & $\begin{array}{c}-0.009 * * * \\
(0.003)\end{array}$ \\
\hline $\mathrm{CN}$ & & $\begin{array}{c}0.165^{* * * *} \\
(0.029)\end{array}$ & & & & & & & & \\
\hline ID & & & $\begin{array}{c}-0.162^{* * *} \\
(0.019)\end{array}$ & & & & & & & $\begin{array}{c}-0.259 \text { *** } \\
(0.028)\end{array}$ \\
\hline MY & & & & $\begin{array}{c}0.143 * * * \\
(0.029)\end{array}$ & & & & & & $\begin{array}{c}0.031 \\
(0.036)\end{array}$ \\
\hline PH & & & & & $\begin{array}{l}-0.017 \\
(0.028)\end{array}$ & & & & & $\begin{array}{c}-0.164^{* * * *} \\
(0.035)\end{array}$ \\
\hline SG & & & & & & $\begin{array}{c}0.082 * * \\
(0.038)\end{array}$ & & & & $\begin{array}{c}0.012 \\
(0.041)\end{array}$ \\
\hline TH & & & & & & & $\begin{array}{c}0.044 \\
(0.032)\end{array}$ & & & $\begin{array}{l}-0.035 \\
(0.039)\end{array}$ \\
\hline VN & & & & & & & & $\begin{array}{l}-0.025 \\
(0.029)\end{array}$ & & $\begin{array}{c}-0.207^{* * *} \\
(0.036)\end{array}$ \\
\hline ASEAN & & & & & & & & & $\begin{array}{c}-0.165^{* * *} \\
(0.029)\end{array}$ & \\
\hline Time trend & & $\begin{array}{c}-0.091^{* * *} \\
(0.013)\end{array}$ & $\begin{array}{c}-0.021 * * * \\
(0.010)\end{array}$ & $\begin{array}{l}-0.011 \\
(0.011)\end{array}$ & $\begin{array}{c}-0.021 \text { * } \\
(0.011)\end{array}$ & $\begin{array}{l}-0.016 \\
(0.011)\end{array}$ & $\begin{array}{l}-0.016 \\
(0.011)\end{array}$ & $\begin{array}{c}-0.018 \text { * } \\
(0.011)\end{array}$ & $\begin{array}{c}-0.091 \text { *** } \\
(0.013)\end{array}$ & $\begin{array}{c}-0.055^{* * *} \\
(0.015)\end{array}$ \\
\hline Constant & & $\begin{array}{c}0.020 * * * \\
(0.062)\end{array}$ & $\begin{array}{c}0.053 \\
(0.060)\end{array}$ & $\begin{array}{c}-0.108 \text { * } \\
(0.063)\end{array}$ & $\begin{array}{c}-0.040 \\
(0.063)\end{array}$ & $\begin{array}{l}-0.048 \\
(0.063)\end{array}$ & $\begin{array}{l}-0.051 \\
(0.063)\end{array}$ & $\begin{array}{l}-0.044 \\
(0.063)\end{array}$ & $\begin{array}{l}0.185 * * \\
(0.072)\end{array}$ & $\begin{array}{l}0.113 \text { * } \\
(0.067)\end{array}$ \\
\hline Pseudo $\mathbf{R}^{2}$ & & 1.2049 & 1.2840 & 1.1862 & 1.1359 & 1.1453 & 1.1392 & 1.1367 & 1.2049 & 1.4195 \\
\hline Adjusted $R^{2}$ & & 0.5216 & 0.5551 & 0.5146 & 0.4976 & 0.5003 & 0.5015 & 0.4978 & 0.5216 & 0.5972 \\
\hline LR chi2 & & 551.76 & 587.97 & 543.15 & 520.12 & 524.43 & 521.65 & 520.51 & 551.76 & 650.01 \\
\hline Prob > chi2 & & 0.00 & 0.00 & 0.00 & 0.00 & 0.00 & 0.00 & 0.00 & 0.00 & 0.00 \\
\hline Log likelihood & & 46.92 & 65.03 & 42.62 & 31.11 & 33.26 & 31.87 & 31.30 & 46.92 & 96.05 \\
\hline Obs. & & 721 & 721 & 721 & 721 & 721 & 721 & 721 & 721 & 721 \\
\hline
\end{tabular}

Dependent variable $=$ DEA score, ${ }^{* * * * *}$, and ${ }^{*}$ represent significance at $1 \%, 5 \%$ and $10 \%$ levels of confidence. ROAA, CAR, NIM, IF, RI, CN, ID, MY, PH, SG, TH and VN refer to return on average assets, capital adequacy ratio, net interest margin, inflation, real interest rate, China, Indonesia, Malaysia, the Philippines, Singapore, Thailand and Vietnam, respectively. All other variables are defined in Table 1. 
Table 13. Determinants of bank efficiency (Tobit regression) post-crisis.

\begin{tabular}{|c|c|c|c|c|c|c|c|c|c|c|}
\hline & Exp. Sign & Model 1 & Model 2 & Model 3 & Model 4 & Model 5 & Model 6 & Model 7 & Model 8 & Model 9 \\
\hline Size & $+1-$ & $\begin{array}{c}0.064^{* * *} \\
(0.005)\end{array}$ & $\begin{array}{c}0.061^{* * *} \\
(0.005)\end{array}$ & $\begin{array}{c}0.062 \text { *** } \\
(0.005)\end{array}$ & $\begin{array}{c}0.059^{* * *} \\
(0.005)\end{array}$ & $\begin{array}{c}0.058^{* * *} \\
(0.005)\end{array}$ & $\begin{array}{c}0.060^{* * *} \\
(0.005)\end{array}$ & $\begin{array}{c}0.062 * * * \\
(0.005)\end{array}$ & $\begin{array}{c}0.064^{* * *} \\
(0.005)\end{array}$ & $\begin{array}{c}0.055^{* * *} \\
(0.005)\end{array}$ \\
\hline ROAA & + & $\begin{array}{c}0.021^{* * *} \\
(0.007)\end{array}$ & $\begin{array}{c}0.022 * * * \\
(0.007)\end{array}$ & $\begin{array}{c}0.022 * * * \\
(0.007)\end{array}$ & $\begin{array}{c}0.026^{* * *} \\
(0.007)\end{array}$ & $\begin{array}{c}0.022 * * * \\
(0.007)\end{array}$ & $\begin{array}{c}0.023^{* * *} \\
(0.007)\end{array}$ & $\begin{array}{c}0.022^{* * * *} \\
(0.007)\end{array}$ & $\begin{array}{c}0.021^{* * *} \\
(0.007)\end{array}$ & $\begin{array}{c}0.026^{* * *} \\
(0.007)\end{array}$ \\
\hline CAR & + & $\begin{array}{c}0.008^{* * *} \\
(0.001)\end{array}$ & $\begin{array}{c}0.008^{* * *} \\
(0.001)\end{array}$ & $\begin{array}{c}0.008^{* * *} \\
(0.001)\end{array}$ & $\begin{array}{c}0.008^{* * *} \\
(0.001)\end{array}$ & $\begin{array}{c}0.007^{* * * *} \\
(0.001)\end{array}$ & $\begin{array}{c}0.008^{* * *} \\
(0.001)\end{array}$ & $\begin{array}{c}0.008^{* * *} \\
(0.001)\end{array}$ & $\begin{array}{c}0.008^{* * *} \\
(0.001)\end{array}$ & $\begin{array}{c}0.007^{* * *} \\
(0.001)\end{array}$ \\
\hline NIM & $+1-$ & $\begin{array}{c}-0.009^{* * * *} \\
(0.003)\end{array}$ & $\begin{array}{c}-0.009^{* * * *} \\
(0.003)\end{array}$ & $\begin{array}{c}-0.009^{* * * *} \\
(0.003)\end{array}$ & $\begin{array}{c}-0.008^{* * * *} \\
(0.003)\end{array}$ & $\begin{array}{c}-0.007^{* * *} \\
(0.003)\end{array}$ & $\begin{array}{c}-0.009^{* * *} \\
(0.003)\end{array}$ & $\begin{array}{c}-0.009^{* * * *} \\
(0.003)\end{array}$ & $\begin{array}{c}-0.009^{* * *} \\
(0.003)\end{array}$ & $\begin{array}{c}-0.005 * \\
(0.003)\end{array}$ \\
\hline GDP & + & $\begin{array}{c}0.019^{* * *} \\
(0.005)\end{array}$ & $\begin{array}{c}0.015^{* * *} \\
(0.004)\end{array}$ & $\begin{array}{c}0.015^{* * *} \\
(0.004)\end{array}$ & $\begin{array}{c}0.013^{* * *} \\
(0.004)\end{array}$ & $\begin{array}{c}0.014^{* * *} \\
(0.004)\end{array}$ & $\begin{array}{c}0.017^{* * *} \\
(0.004)\end{array}$ & $\begin{array}{c}0.015^{* * *} \\
(0.004)\end{array}$ & $\begin{array}{c}0.019 * * * \\
(0.005)\end{array}$ & $\begin{array}{c}0.019^{* * *} \\
(0.005)\end{array}$ \\
\hline IF & - & $\begin{array}{c}-0.027^{* * * *} \\
(0.003)\end{array}$ & $\begin{array}{c}-0.025^{* * * *} \\
(0.003)\end{array}$ & $\begin{array}{c}-0.025^{* * * *} \\
(0.003)\end{array}$ & $\begin{array}{c}-0.027^{* * * *} \\
(0.003)\end{array}$ & $\begin{array}{c}-0.026^{* * *} \\
(0.003)\end{array}$ & $\begin{array}{c}-0.024^{* * *} \\
(0.003)\end{array}$ & $\begin{array}{c}-0.025^{* * *} \\
(0.004)\end{array}$ & $\begin{array}{c}-0.027^{* * * *} \\
(0.003)\end{array}$ & $\begin{array}{c}-0.028^{* * *} \\
(0.005)\end{array}$ \\
\hline RI & - & $\begin{array}{c}-0.027^{* * * *} \\
(0.003)\end{array}$ & $\begin{array}{c}-0.024^{* * * *} \\
(0.004)\end{array}$ & $\begin{array}{c}-0.025^{* * * *} \\
(0.003)\end{array}$ & $\begin{array}{c}-0.027^{* * * *} \\
(0.003)\end{array}$ & $\begin{array}{c}-0.029^{* * * *} \\
(0.003)\end{array}$ & $\begin{array}{c}-0.025^{* * * *} \\
(0.003)\end{array}$ & $\begin{array}{c}-0.025^{* * * *} \\
(0.003)\end{array}$ & $\begin{array}{c}-0.027^{* * * *} \\
(0.003)\end{array}$ & $\begin{array}{c}-0.029^{* * *} \\
(0.005)\end{array}$ \\
\hline $\mathrm{CN}$ & & $\begin{array}{c}-0.038 \text { * } \\
(0.023)\end{array}$ & & & & & & & & \\
\hline ID & & & $\begin{array}{l}-0.017 \\
(0.024)\end{array}$ & & & & & & & $\begin{array}{c}0.009 \\
(0.034)\end{array}$ \\
\hline MY & & & & $\begin{array}{c}0.009 \\
(0.029)\end{array}$ & & & & & & $\begin{array}{c}0.030 \\
(0.031)\end{array}$ \\
\hline PH & & & & & $\begin{array}{c}-0.121^{* * *} \\
(0.030)\end{array}$ & & & & & $\begin{array}{c}-0.101^{* * *} \\
(0.033)\end{array}$ \\
\hline SG & & & & & & $\begin{array}{c}0.327^{* * * *} \\
(0.044)\end{array}$ & & & & $\begin{array}{c}0.344^{* * *} \\
(0.046)\end{array}$ \\
\hline TH & & & & & & & $\begin{array}{l}0.052 * \\
(0.031)\end{array}$ & & & $\begin{array}{l}0.079 * * \\
(0.035)\end{array}$ \\
\hline VN & & & & & & & & $\begin{array}{l}-0.001 \\
(0.034)\end{array}$ & & $\begin{array}{c}0.030 \\
(0.044)\end{array}$ \\
\hline ASEAN & & & & & & & & & $\begin{array}{l}0.038 * \\
(0.023)\end{array}$ & \\
\hline Time trend & & $\begin{array}{c}-0.026^{* *} \\
(0.010)\end{array}$ & $\begin{array}{c}-0.037^{* * * *} \\
(0.010)\end{array}$ & $\begin{array}{c}-0.026^{* * *} \\
(0.009)\end{array}$ & $\begin{array}{c}-0.026^{* * *} \\
(0.009)\end{array}$ & $\begin{array}{c}-0.018^{* *} \\
(0.009)\end{array}$ & $\begin{array}{c}-0.024^{* * *} \\
(0.009)\end{array}$ & $\begin{array}{c}-0.026^{* * *} \\
(0.009)\end{array}$ & $\begin{array}{c}-0.026^{* *} \\
(0.010)\end{array}$ & $\begin{array}{c}-0.026^{* *} \\
(0.012)\end{array}$ \\
\hline Constant & & $\begin{array}{c}0.019 \\
(0.067)\end{array}$ & $\begin{array}{c}0.038 \\
(0.066)\end{array}$ & $\begin{array}{c}0.029 \\
(0.071)\end{array}$ & $\begin{array}{c}0.090 \\
(0.067)\end{array}$ & $\begin{array}{c}0.069 \\
(0.066)\end{array}$ & $\begin{array}{c}0.019 \\
(0.067)\end{array}$ & $\begin{array}{c}0.037 \\
(0.067)\end{array}$ & $\begin{array}{l}-0.019 \\
(0.074)\end{array}$ & $\begin{array}{c}0.064 \\
(0.077)\end{array}$ \\
\hline Pseudo $\mathrm{R}^{2}$ & & 0.4937 & 0.4913 & 0.4909 & 0.5081 & 0.5503 & 0.4937 & 0.4908 & 0.4937 & 0.5735 \\
\hline Adjusted $R^{2}$ & & 0.3247 & 0.3236 & 0.3233 & 0.3330 & 0.3486 & 0.3267 & 0.3233 & 0.3247 & 0.3602 \\
\hline
\end{tabular}


Table 13. Cont.

\begin{tabular}{ccccccccccc}
\hline & Exp. Sign & Model 1 & Model 2 & Model 3 & Model 4 & Model 5 & Model 6 & Model 7 & Model 8 & Model 9 \\
\hline LR chi2 & & 477.96 & 475.60 & 475.22 & 491.83 & 532.75 & 477.93 & 475.12 & 477.96 & 555.15 \\
Prob > chi2 & & 0.00 & 0.00 & 0.00 & 0.00 & 0.00 & 0.00 & 0.00 & 0.00 & 0.00 \\
Log likelihood & -245.05 & -246.24 & -246.43 & -238.12 & -217.66 & -245.07 & -246.48 & -245.05 & -206.46 \\
Obs. & 1275 & 1275 & 1275 & 1275 & 1275 & 1275 & 1275 & 1275 & 1275 & \\
\hline
\end{tabular}

Dependent variable $=$ DEA score, ${ }^{* * *}, * *$, and ${ }^{*}$ represent significance at $1 \%, 5 \%$ and $10 \%$ levels of confidence. ROAA, CAR, NIM, IF, RI, CN, ID, MY, PH, SG, TH and VN refer to return on average assets, capital adequacy ratio, net interest margin, inflation, real interest rate, China, Indonesia, Malaysia, the Philippines, Singapore, Thailand and Vietnam, respectively. All other variables are defined in Table 1 .

Table 14. Determinants of bank efficiency (bootstrap (1000 replication) Tobit regression) with the geographical location effect.

\begin{tabular}{|c|c|c|c|c|c|c|c|c|c|c|}
\hline & Exp. Sign & Model 1 & Model 2 & Model 3 & Model 4 & Model 5 & Model 6 & Model 7 & Model 8 & Model 9 \\
\hline Size & $+/-$ & $\begin{array}{c}0.031^{* * *} \\
(0.003)\end{array}$ & $\begin{array}{c}0.032 * * * \\
(0.003)\end{array}$ & $\begin{array}{c}0.034^{* * *} \\
(0.003)\end{array}$ & $\begin{array}{c}0.032^{* * *} \\
(0.003)\end{array}$ & $\begin{array}{c}0.032 * * * \\
(0.003)\end{array}$ & $\begin{array}{c}0.033^{* * *} \\
(0.003)\end{array}$ & $\begin{array}{c}0.033^{* * *} \\
(0.003)\end{array}$ & $\begin{array}{c}0.031^{* * *} \\
(0.003)\end{array}$ & $\begin{array}{c}0.021^{* * *} \\
(0.003)\end{array}$ \\
\hline ROAA & + & $\begin{array}{l}0.008^{*} \\
(0.004)\end{array}$ & $\begin{array}{l}0.008^{*} \\
(0.004)\end{array}$ & $\begin{array}{l}0.007^{*} \\
(0.004)\end{array}$ & $\begin{array}{l}0.007^{*} \\
(0.004)\end{array}$ & $\begin{array}{l}0.007^{*} \\
(0.004)\end{array}$ & $\begin{array}{l}0.008^{*} \\
(0.005)\end{array}$ & $\begin{array}{l}0.008^{*} \\
(0.004)\end{array}$ & $\begin{array}{l}0.008^{*} \\
(0.005)\end{array}$ & $\begin{array}{l}0.008^{*} \\
(0.005)\end{array}$ \\
\hline CAR & + & $\begin{array}{c}0.006^{* * * *} \\
(0.001)\end{array}$ & $\begin{array}{c}0.006^{* * *} \\
(0.001)\end{array}$ & $\begin{array}{c}0.006^{* * * *} \\
(0.001)\end{array}$ & $\begin{array}{c}0.006^{* * *} \\
(0.001)\end{array}$ & $\begin{array}{c}0.006^{* * * *} \\
(0.001)\end{array}$ & $\begin{array}{c}0.006^{* * *} \\
(0.001)\end{array}$ & $\begin{array}{c}0.007^{* * *} \\
(0.001)\end{array}$ & $\begin{array}{c}0.006^{* * * *} \\
(0.001)\end{array}$ & $\begin{array}{c}0.005^{* * *} \\
(0.001)\end{array}$ \\
\hline NIM & $+1-$ & $\begin{array}{c}-0.016^{* * *} \\
(0.003)\end{array}$ & $\begin{array}{c}-0.016^{* * *} \\
(0.003)\end{array}$ & $\begin{array}{c}-0.016^{* * *} \\
(0.003)\end{array}$ & $\begin{array}{c}-0.015^{* * *} \\
(0.003)\end{array}$ & $\begin{array}{c}-0.015^{* * *} \\
(0.003)\end{array}$ & $\begin{array}{c}-0.016^{* * *} \\
(0.003)\end{array}$ & $\begin{array}{c}-0.018^{* * *} \\
(0.003)\end{array}$ & $\begin{array}{c}-0.016^{* * *} \\
(0.003)\end{array}$ & $\begin{array}{c}-0.012^{* * *} \\
(0.003)\end{array}$ \\
\hline GDP & + & $\begin{array}{c}0.016^{* * *} \\
(0.003)\end{array}$ & $\begin{array}{c}0.021^{* * *} \\
(0.002)\end{array}$ & $\begin{array}{c}0.023^{* * *} \\
(0.002)\end{array}$ & $\begin{array}{c}0.019^{* * *} \\
(0.002)\end{array}$ & $\begin{array}{c}0.022 * * * \\
(0.002)\end{array}$ & $\begin{array}{c}0.022^{* * *} \\
(0.002)\end{array}$ & $\begin{array}{c}0.021^{* * *} \\
(0.002)\end{array}$ & $\begin{array}{c}0.016^{* * *} \\
(0.003)\end{array}$ & $\begin{array}{c}0.019^{* * *} \\
(0.003)\end{array}$ \\
\hline IF & - & $\begin{array}{c}-0.0211^{* * *} \\
(0.002)\end{array}$ & $\begin{array}{c}-0.021^{* * *} \\
(0.002)\end{array}$ & $\begin{array}{c}-0.021 \text { *** } \\
(0.002)\end{array}$ & $\begin{array}{c}-0.023^{* * *} \\
(0.002)\end{array}$ & $\begin{array}{c}-0.022 * * * \\
(0.002)\end{array}$ & $\begin{array}{c}-0.022 * * * \\
(0.002)\end{array}$ & $\begin{array}{c}-0.020 * * * \\
(0.002)\end{array}$ & $\begin{array}{c}-0.021 \text { *** } \\
(0.002)\end{array}$ & $\begin{array}{c}-0.011 \text { *** } \\
(0.002)\end{array}$ \\
\hline RI & - & $\begin{array}{c}-0.010 * * * \\
(0.002)\end{array}$ & $\begin{array}{c}-0.009^{* * *} \\
(0.002)\end{array}$ & $\begin{array}{c}-0.009^{* * *} \\
(0.002)\end{array}$ & $\begin{array}{c}-0.010 * * * \\
(0.002)\end{array}$ & $\begin{array}{c}-0.010^{* * *} \\
(0.002)\end{array}$ & $\begin{array}{c}-0.010 * * * \\
(0.002)\end{array}$ & $\begin{array}{c}-0.010 * * * \\
(0.002)\end{array}$ & $\begin{array}{c}-0.010 * * * \\
(0.002)\end{array}$ & $\begin{array}{c}-0.005^{* *} \\
(0.002)\end{array}$ \\
\hline $\mathrm{CN}$ & & $\begin{array}{c}0.050 * * * \\
(0.018)\end{array}$ & & & & & & & & \\
\hline ID & & & $\begin{array}{c}-0.034 \text { ** } \\
(0.015)\end{array}$ & & & & & & & $\begin{array}{c}-0.133^{* * *} \\
(0.024)\end{array}$ \\
\hline MY & & & & $\begin{array}{c}0.054^{* * *} \\
(0.019)\end{array}$ & & & & & & $\begin{array}{c}0.015 \\
(0.025)\end{array}$ \\
\hline PH & & & & & $\begin{array}{c}-0.106^{* * *} \\
(0.016)\end{array}$ & & & & & $\begin{array}{c}-0.170 \text { *** } \\
(0.023)\end{array}$ \\
\hline SG & & & & & & $\begin{array}{c}0.182 * * * \\
(0.036)\end{array}$ & & & & $\begin{array}{c}0.144^{* * *} \\
(0.040)\end{array}$ \\
\hline
\end{tabular}


Table 14. Cont.

\begin{tabular}{|c|c|c|c|c|c|c|c|c|c|c|}
\hline & Exp. Sign & Model 1 & Model 2 & Model 3 & Model 4 & Model 5 & Model 6 & Model 7 & Model 8 & Model 9 \\
\hline TH & & & & & & & $\begin{array}{c}0.038^{* *} \\
(0.019)\end{array}$ & & & $\begin{array}{l}-0.001 \\
(0.025)\end{array}$ \\
\hline VN & & & & & & & & $\begin{array}{c}-0.070 * * * \\
(0.019)\end{array}$ & & $\begin{array}{c}-0.161 \text { *** } \\
(0.027)\end{array}$ \\
\hline ASEAN & & & & & & & & & $\begin{array}{c}-0.050^{* * *} \\
(0.019)\end{array}$ & \\
\hline Time trend & & $\begin{array}{c}-0.042 * * * \\
(0.001)\end{array}$ & $\begin{array}{c}-0.040^{* * *} \\
(0.001)\end{array}$ & $\begin{array}{c}-0.039 \text { *** } \\
(0.001)\end{array}$ & $\begin{array}{c}-0.039 * * * \\
(0.001)\end{array}$ & $\begin{array}{c}-0.039 * * * \\
(0.001)\end{array}$ & $\begin{array}{c}-0.040^{* * *} \\
(0.001)\end{array}$ & $\begin{array}{c}-0.039 * * * \\
(0.001)\end{array}$ & $\begin{array}{c}-0.041^{* * *} \\
(0.001)\end{array}$ & $\begin{array}{c}-0.041^{* * *} \\
(0.001)\end{array}$ \\
\hline Constant & & $\begin{array}{c}0.389 * * * \\
(0.044)\end{array}$ & $\begin{array}{c}0.371^{* * *} \\
(0.042)\end{array}$ & $\begin{array}{c}0.324^{* * *} \\
(0.043)\end{array}$ & $\begin{array}{c}0.383^{* * *} \\
(0.042)\end{array}$ & $\begin{array}{c}0.354^{* * *} \\
(0.041)\end{array}$ & $\begin{array}{c}0.348^{* * *} \\
(0.041)\end{array}$ & $\begin{array}{c}0.364^{* * *} \\
(0.042)\end{array}$ & $\begin{array}{c}0.439 * * * \\
(0.051)\end{array}$ & $\begin{array}{c}0.452 * * * \\
(0.050)\end{array}$ \\
\hline Pseudo $R^{2}$ & & 0.3571 & 0.3558 & 0.3569 & 0.3652 & 0.3698 & 0.3551 & 0.3596 & 0.3571 & 0.4088 \\
\hline LR chi2 & & 883.59 & 956.98 & 875.51 & 942.65 & 963.31 & 925.59 & 796.69 & 936.89 & 1163.0 \\
\hline Prob > chi2 & & 0.00 & 0.00 & 0.00 & 0.00 & 0.00 & 0.00 & 0.00 & 0.00 & 0.00 \\
\hline Log likelihood & & -782.25 & -783.91 & -782.48 & -772.38 & -766.79 & -784.72 & -779.21 & -782.25 & -719.31 \\
\hline Obs. & & 2860 & 2860 & 2860 & 2860 & 2860 & 2860 & 2860 & 2860 & 2860 \\
\hline
\end{tabular}

Dependent variable $=$ DEA score, ${ }^{* * *}, * *$, and ${ }^{*}$ represent significance at $1 \%, 5 \%$ and $10 \%$ levels of confidence. ROAA, CAR, NIM, IF, RI, CN, ID, MY, PH, SG, TH and VN refer to return on average assets, capital adequacy ratio, net interest margin, inflation, real interest rate, China, Indonesia, Malaysia, the Philippines, Singapore, Thailand and Vietnam, respectively. All other variables are defined in Table 1 . 
The results of the double bootstrap regression model suggest that Chinese banks outperform ASEAN banks in terms of efficiency and that the GFC had a significant impact on bank efficiency in Sino-ASEAN countries. These results are similar to our earlier findings. Likewise, all the results for the control variables were similar to our previous direct Tobit regression and bootstrapping Tobit regression models. Overall, these findings suggest that although direct Tobit regression may yield misleading results, however, in the case of this study, the results are reliable, as verified by the bootstrapping and double bootstrapping regression models.

Table 15. Determinants of bank efficiency (bootstrap (2000 replication) Simar and Wilson 2007 regression) with geographical location effect.

\begin{tabular}{|c|c|c|c|c|}
\hline Dep. Var: Efficiency Score & Exp. Sign & Model 1 & Model 2 & Model 3 \\
\hline Size & $+/-$ & $\begin{array}{c}0.061^{* * *} \\
(0.004)\end{array}$ & $\begin{array}{c}0.061^{* * *} \\
(0.003)\end{array}$ & $\begin{array}{c}0.062^{* * *} \\
(0.003)\end{array}$ \\
\hline ROAA & + & $\begin{array}{c}0.010^{* * *} \\
(0.003)\end{array}$ & $\begin{array}{c}0.010^{* * *} \\
(0.003)\end{array}$ & $\begin{array}{c}0.010^{* * *} \\
(0.003)\end{array}$ \\
\hline CAR & + & $\begin{array}{c}0.005^{* * *} \\
(0.001)\end{array}$ & $\begin{array}{c}0.005^{* * *} \\
(0.001)\end{array}$ & $\begin{array}{c}0.005^{* * *} \\
(0.001)\end{array}$ \\
\hline NIM & $+1-$ & $\begin{array}{c}-0.008^{* * *} \\
(0.002)\end{array}$ & $\begin{array}{c}-0.008^{* * *} \\
(0.002)\end{array}$ & $\begin{array}{c}-0.008^{* * *} \\
(0.002)\end{array}$ \\
\hline GDP & + & $\begin{array}{c}0.007^{* * *} \\
(0.002)\end{array}$ & $\begin{array}{c}0.007^{* * *} \\
(0.002)\end{array}$ & $\begin{array}{c}0.008^{* * *} \\
(0.002)\end{array}$ \\
\hline IF & - & $\begin{array}{c}-0.017^{* * *} \\
(0.001)\end{array}$ & $\begin{array}{c}-0.017^{* * *} \\
(0.001)\end{array}$ & $\begin{array}{c}-0.016^{* * *} \\
(0.001)\end{array}$ \\
\hline RI & - & $\begin{array}{c}-0.007^{* * *} \\
(0.001)\end{array}$ & $\begin{array}{c}-0.007^{* * *} \\
(0.002)\end{array}$ & $\begin{array}{c}-0.006^{* * *} \\
(0.002)\end{array}$ \\
\hline $\mathrm{CN}$ & & $\begin{array}{c}0.092^{* * *} \\
(0.015)\end{array}$ & & \\
\hline ASEAN & & & $\begin{array}{c}-0.092^{* * *} \\
(0.015)\end{array}$ & \\
\hline Crisis & & & & $\begin{array}{c}0.039 * * * \\
(0.010)\end{array}$ \\
\hline Time trend & & $\begin{array}{c}-0.042^{* * *} \\
(0.001)\end{array}$ & $\begin{array}{c}-0.042^{* * *} \\
(0.001)\end{array}$ & $\begin{array}{c}-0.041^{* * *} \\
(0.002)\end{array}$ \\
\hline Wald chi ${ }^{2}$ & & 1144.54 & 1138.16 & 1174.93 \\
\hline Prob $>$ chi $^{2}$ & & 0.0000 & 0.0000 & 0.0000 \\
\hline Obs. & & 2347 & 2347 & 2347 \\
\hline
\end{tabular}

Dependent variable $=$ DEA score, ${ }^{* * *}, * *$, and ${ }^{*}$ represent significance at $1 \%, 5 \%$ and $10 \%$ levels of confidence. ROAA, CAR, NIM, IF, RI and CN refer to return on average assets, capital adequacy ratio, net interest margin, inflation, real interest rate and China, respectively. Crisis refers to the global financial crisis. All other variables are defined in Table 1.

\section{Conclusions and Recommendation}

The main objective of this paper was to assess the importance of the geographical location effect on banking sector efficiency in the Sino-ASEAN region. We extended our analysis further by studying the significance of the geographical effect during and around the global financial crisis. DEA based efficiency scores were first derived as a proxy to banking sector efficiency across the region to be evaluated through Tobit regression and the Simar and Wilson (2007) double bootstrapping method.

The results suggest that Chinese banks have a dominating power in the formulation of the frontier. After China, Malaysian banks contribute most to the efficiency frontier, followed by Singapore. The contribution of Chinese banks in the efficiency frontier matters a lot. Although the Chinese banking sector is outperforming the ASEAN banking sector in terms of efficiency, the Chinese banking sector efficiency sharply declines over the period. Hence, the overall efficiency frontier is contracting and China is driving that contraction. The results clearly indicate the significance of country-specific factors in explaining banking sector efficiency across the region. One of the contributions of this paper was to assess the role of country-specific aspects during and around the global financial crisis. Our piecewise 
regression for the pre-crisis, crisis and post-crisis periods suggests that the geographical location effect was a significant determinant of banking sector efficiency throughout the period of our analysis. The results indicate that much of the variation in the efficiency of banking markets in the Sino-ASEAN region are due to the geographical location and country-specific factors. Similar to the findings of earlier studies in Europe (Pastor et al. 1997), our study confirms the role of country-specific factors as the major determinants of banking efficiency level across the Sino-ASEAN region. Xue and Harker (1999) identified the dependency problem in DEA based scores, which contradicts with the basic regression model. The presence of a dependency problem thus may lead to unverifiable results. Following the authors' suggestion, bootstrapping and double bootstrapping were used to overcome this problem. The results, however, were consistent with the direct Tobit regression.

Policymakers, regulators and investors should closely monitor the performance of banking in the Sino-ASEAN region. Although China and Singapore are performing better as compared to other countries in the region, policymakers and regulators should be more vigilant while following the strategic policies of liberalization, regulation and consolidation in these two countries. Policymakers might place emphasis on mitigating non-performing loans and special mention loans that may potentially reduce the efficiency level of Chinese banks. In the ASEAN region, which consists of countries with different stages of economic and financial development, there also exists a big problem in the harmonization of regulations, in terms of which criterion should be based. To accommodate the various risks entailed in the harmonization process, it will be necessary to allow some room for flexibility to member states. For instance, when the entry criteria of foreign banks may be too liberal to some of the member states, there will be a risk that foreign banks with loose risk management will be allowed to enter into such countries, destabilizing the financial system of them. In such a case, it may become necessary for them to take some discriminatory treatments (from domestic banks), depending on the risk management capacity of the entering banks. On the other hand, in the case of a country with a less developed financial market, there is a risk that its domestic market will be dominated by foreign banks. In this case, there will be a need to allow the country to put off the entry liberalization schedule or put a ceiling on the share of foreign banks in the domestic market. This research can be extended further by analyzing the dynamic relationship of the regulatory framework, ownership structure and bank efficiency in the Sino-ASEAN region, as well as other Asian countries.

Author Contributions: Conceptualization, H.B. and A.H.M.N.; Formal analysis, S.K.B.S. and H.B.; Investigation, H.B., S.K.B.S. and A.H.M.N.; Methodology, H.B.; Resources, H.B.; Software, H.B.; Writing-original draft, H.B.; Writing-review \& editing, H.B., S.K.B.S., A.H.M.N., R.A., and M.M.M.

Funding: This research was funded by Centre for Poverty and Development Studies (CPDS)/Ungku Aziz Centre for Development Studies, Faculty of Economics and Administration, University of Malaya, grant number: PD004-2018.

Acknowledgments: Authors would like to thank Koh Hsieng Yang Eric, Chan Sok Gee, Aslam Mia, Md Sohel Rana and Centre for Poverty and Development Studies (CPDS) for their critical review, precious comments and technical support.

Conflicts of Interest: The authors declare no conflict of interest.

\section{References}

Abd Karim, Mohd Zaini. 2001. Comparative bank efficiency across select ASEAN countries. ASEAN Economic Bulletin 18: 289-304. [CrossRef]

ADB, ASEAN. 2013. The Road to ASEAN Financial Integration: A Combined Study on Assessing the Financial Landscape and Formulating Milestones for Monetary and Financial Integration in ASEAN. Manila: Asian Development Bank.

Allen, Linda, and Anoop Rai. 1996. Operational efficiency in banking: An international comparison. Journal of Banking \& Finance 20: 655-72.

Altunbas, Y., M. H. Liu, P. Molyneux, and R. Seth. 2000. Efficiency and risk in Japanese banking. Journal of Banking E Finance 24: 1605-28.

Athanasoglou, Panayiotis, Manthos Delis, and Christos Staikouras. 2008. Determinants of Bank Profitability in the South Eastern European Region. Journal of Financial Decision Making 2: 1-17. 
Atkinson, Scott E., and Paul W. Wilson. 1995. Comparing mean efficiency and productivity scores from small samples: A bootstrap methodology. Journal of Productivity Analysis 6: 137-52. [CrossRef]

Banna, Hasanul, Rubi Ahmad, and Eric HY Koh. 2017. Determinants of Commercial Banks' Efficiency in Bangladesh: Does Crisis Matter? The Journal of Asian Finance, Economics and Business 4: 19-26. [CrossRef]

Banna, Hasanul, Rubi Ahmad, and Eric H. Y. Koh. 2018. How does total quality management influence the loan quality of the bank? Total Quality Management \& Business Excellence 29: 287-300. [CrossRef]

Barry, Thierno Amadou, Laetitia Lepetita, and Amine Tarazia. 2010. Ownership Structure and Bank Efficiency in Six Asian Countries. Philippine Management Review (Special Issue) 18: 19-35.

Berger, Allen N. 1995. The profit-structure relationship in banking-Tests of market-power and efficient-structure hypotheses. Journal of Money, Credit and Banking 27: 404-31. [CrossRef]

Berger, Allen N., and David B. Humphrey. 1997. Efficiency of financial institutions: International survey and directions for future research. European Journal of Operational Research 98: 175-212. [CrossRef]

Berger, Allen N., Iftekhar Hasan, and Mingming Zhou. 2009. Bank ownership and efficiency in China: What will happen in the world's largest nation? Journal of Banking $\mathcal{E}$ Finance 33: 113-30.

Carbo, Santiago, Edward P. M. Gardener, and Jonathan Williams. 2003. A note on technical change in banking: The case of European savings banks. Applied Economics 35: 705-19. [CrossRef]

Casu, Barbara, and Philip Molyneux. 2003. A comparative study of efficiency in European banking. Applied Economics 35: 1865-76. [CrossRef]

Chan, Sok-Gee, Eric H. Y. Koh, Fauzi Zainir, and Chen-Chen Yong. 2015. Market structure, institutional framework and bank efficiency in ASEAN 5. Journal of Economics and Business 82: 84-112. [CrossRef]

Coelli, Tim, D. S. Prasada Rao, and George E. Battese. 1998. An Introduction to Efficiency and Productivity. Boston: Analysis, Kluwer Academic Publishers.

Dacanay, Santos José O. 2007. Profit and cost efficiency of Philippine commercial banks under periods of liberalization, crisis and consolidation. The Business Review 7: 315-22.

Daraio, Cinzia, Léopold Simar, and Paul W. Wilson. 2018. Central limit theorems for conditional efficiency measures and tests of the 'separability' condition in non-parametric, two-stage models of production. The Econometrics Journal 21: 170-91. [CrossRef]

Demirgüç-Kunt, Ash, and Harry Huizinga. 1999. Determinants of commercial bank interest margins and profitability: Some international evidence. The World Bank Economic Review 13: 379-408. [CrossRef]

Dong, Yizhe, Robert Hamilton, and Mark Tippett. 2014. Cost efficiency of the Chinese banking sector: A comparison of stochastic frontier analysis and data envelopment analysis. Economic Modelling 36: 298-308. [CrossRef]

Dougherty, Christopher. 2001. Introduction to Econometrics. Oxford: Oxford University Press.

Efron, Bradley. 1979. Bootstrap methods: Another look at the jackknife. The Annals of Statistics 7: 1-26. [CrossRef]

Ferrier, Gary D., and Vivian Valdmanis. 1996. Rural hospital performance and its correlates. Journal of Productivity Analysis 7: 63-80. [CrossRef]

Fried, Harold O., C. A. Knox Lovell, and Shelton S. Schmidt. 1993. The Measurement of Productive Efficiency: Techniques and Applications. Oxford: Oxford University Press.

Fries, Steven, and Anita Taci. 2005. Cost efficiency of banks in transition: Evidence from 289 banks in 15 post-communist countries. Journal of Banking \& Finance 29: 55-81. [CrossRef]

Fukuyama, Hirofumi, and Roman Matousek. 2011. Efficiency of Turkish banking: Two-stage network system. Variable returns to scale model. Journal of International Financial Markets, Institutions and Money 21: 75-91. [CrossRef]

Goddard, John, Phil Molyneux, and John O. S. Wilson. 2004. The profitability of European banks: A cross-sectional and dynamic panel analysis. The Manchester School 72: 363-81. [CrossRef]

Grigorian, David A., and Vlad Manole. 2006. Determinants of commercial bank performance in transition: An application of data envelopment analysis. Comparative Economic Studies 48: 497-522. [CrossRef]

Grosskopf, Shawna. 1996. Statistical inference and nonparametric efficiency: A selective survey. Journal of Productivity Analysis 7: 161-76. [CrossRef]

Hadad, Muliaman D., Maximilian J. B. Hall, Karligash A. Kenjegalieva, Wimboh Santoso, and Richard Simper. 2011a. Banking efficiency and stock market performance: An analysis of listed Indonesian banks. Review of Quantitative Finance and Accounting 37: 1-20. [CrossRef] 
Hadad, Muliaman D., Maximilian J. B. Hall, Karligash A. Kenjegalieva, Wimboh Santoso, and Richard Simper. 2011b. Productivity changes and risk management in Indonesian banking: A Malmquist analysis. Applied Financial Economics 21: 847-61. [CrossRef]

Hasan, Iftekhar, and Katherin Marton. 2003. Development and efficiency of the banking sector in a transitional economy: Hungarian experience. Journal of Banking $\mathcal{E}$ Finance 27: 2249-71. [CrossRef]

Heffernan, Shelagh A., and Xiaoqing Fu. 2010. Determinants of financial performance in Chinese banking. Applied Financial Economics 20: 1585-600. [CrossRef]

Honohan, Patrick, and Daniela Klingebiel. 2003. The fiscal cost implications of an accommodating approach to banking crises. Journal of Banking E Finance 27: 1539-60. [CrossRef]

Jiang, Chunxia, Genfu Feng, and Dirk Willenbockel. 2007. WTO challenges and efficiency of Chinese banks AU-Yao, Shujie. Applied Economics 39: 629-43. [CrossRef]

Kaparakis, Emmanuel I., Stephen M. Miller, and Athanasios G. Noulas. 1994. Short-run cost inefficiency of commercial banks: A flexible stochastic frontier approach. Journal of Money, Credit and Banking 26: 875-93. [CrossRef]

Kwack, Sung Yeung. 2000. An empirical analysis of the factors determining the financial crisis in Asia. Journal of Asian Economics 11: 195-206. [CrossRef]

Lovell, C. A. Knox, Jesús T. Pastor, and Judi A. Turner. 1995. Measuring macroeconomic performance in the OECD: A comparison of European and non-European countries. European Journal of Operational Research 87: 507-18. [CrossRef]

Lozano-Vivas, Ana, Jesus T. Pastor, and José M. Pastor. 2002. An efficiency comparison of European banking systems operating under different environmental conditions. Journal of Productivity Analysis 18: 59-77. [CrossRef]

Maddala, Gangadharrao S., and Shaowen Wu. 1999. A comparative study of unit root tests with panel data and a new simple test. Oxford Bulletin of Economics and Statistics 61: 631-52. [CrossRef]

Manlagñit, Maria Chelo V. 2011. Cost efficiency, determinants, and risk preferences in banking: A case of stochastic frontier analysis in the Philippines. Journal of Asian Economics 22: 23-35. [CrossRef]

Margono, Heru, Subhash C. Sharma, and Paul D. Melvin. 2010. Cost efficiency, economies of scale, technological progress and productivity in Indonesian banks. Journal of Asian Economics 21: 53-65. [CrossRef]

Matthews, Kent, and Mahadzir Ismail. 2006. Efficiency and Productivity Growth of Domestic and Foreign Commercial Banks in Malaysia. Cardiff: Cardiff University.

Mester, Loretta J. 1996. A study of bank efficiency taking into account risk-preferences. Journal of Banking $\mathcal{E}$ Finance 20: $1025-45$.

Mia, Md Aslam, Lucia Dalla Pellegrina, Patrick Van Damme, and Mahinda Wijesiri. 2018. Financial Inclusion, Deepening and Efficiency in Microfinance Programs: Evidence from Bangladesh. The European Journal of Development Research. [CrossRef]

Molyneux, Philip. 1993. Structure and Performance in European Banking. Bangor: University of Wales.

Molyneux, Philip, Linh H. Nguyen, and Ru Xie. 2013. Foreign bank entry in South East Asia. International Review of Financial Analysis 30: 26-35. [CrossRef]

Noman, Abu Hanifa Md, Chan Sok Gee, and Che Ruhana Isa. 2017. Does competition improve financial stability of the banking sector in ASEAN countries? An empirical analysis. PLoS ONE 12: e0176546. [CrossRef] [PubMed]

Noman, Abu Hanifa Md, Chan Sok Gee, and Che Ruhana Isa. 2018. Does bank regulation matter on the relationship between competition and financial stability? Evidence from Southeast Asian countries. Pacific-Basin Finance Journal 48: 144-61. [CrossRef]

Nurboja, Bashkim, and Marko Košak. 2017. Banking efficiency in South East Europe: Evidence for financial crises and the gap between new EU members and candidate countries. Economic Systems 41: 122-38. [CrossRef]

Parinduri, Rasyad A., and Yohanes E. Riyanto. 2014. Bank Ownership and Efficiency in the Aftermath of Financial Crises: Evidence from Indonesia. Review of Development Economics 18: 93-106. [CrossRef]

Pastor, JoséManuel, Francisco Perez, and Javier Quesada. 1997. Efficiency analysis in banking firms: An international comparison. European Journal of Operational Research 98: 395-407. [CrossRef]

Perry, Philip. 1992. Do banks gain or lose from inflation? Journal of Retail Banking 14: 25-31.

Qin, Xuezhi, and Dickson Pastory. 2012. Commercial Banks Profitability Position: The Case of Tanzania. International Journal of Business \& Management 7. [CrossRef] 
Schaeck, Klaus, and Martin Cihák. 2014. Competition, efficiency, and stability in banking. Financial Management 43: 215-41. [CrossRef]

Simar, Leopold, and Paul W. Wilson. 1998. Sensitivity analysis of efficiency scores: How to bootstrap in nonparametric frontier models. Management Science 44: 49-61. [CrossRef]

Simar, Leopold, and Paul W. Wilson. 2007. Estimation and inference in two-stage, semi-parametric models of production processes. Journal of econometrics 136: 31-64. [CrossRef]

Simar, Léopold, and Paul W. Wilson. 2011. Two-stage DEA: Caveat emptor. Journal of Productivity Analysis 36: 205. [CrossRef]

Soedarmono, Wahyoe, Fouad Machrouh, and Amine Tarazi. 2013. Bank competition, crisis and risk taking: Evidence from emerging markets in Asia. Journal of International Financial Markets, Institutions and Money 23: 196-221. [CrossRef]

Sufian, Fadzlan. 2009. Determinants of bank efficiency during unstable macroeconomic environment: Empirical evidence from Malaysia. Research in International Business and Finance 23: 54-77. [CrossRef]

Sufian, Fadzlan. 2010. The impact of the Asian financial crisis on bank efficiency: The 1997 experience of Malaysia and Thailand. Journal of International Development 22: 866-89. [CrossRef]

Sufian, Fadzlan, and M. Shah Habibullah. 2009. Do mergers and acquisitions leads to a higher technical and scale efficiency? A counter evidence from Malaysia. African Journal of Business Management 3: 340-49.

Sufian, Fadzlan, and Muzafar Shah Habibullah. 2010. Developments in the efficiency of the Thailand banking sector: A DEA approach. International Journal of Development Issues 9: 226-45. [CrossRef]

Tajgardoon, Gholamreza, Mehdi Behname, and Khosro Noormohamadi. 2012. Is Profitability as a result of Market Power or Efficiency in Islamic Banking Industry. Economics and Finance Review 2: 1-7.

Thoraneenitiyan, Nakhun, and Necmi K. Avkiran. 2009. Measuring the impact of restructuring and country-specific factors on the efficiency of post-crisis East Asian banking systems: Integrating DEA with SFA. Socio-Economic Planning Sciences 43: 240-52. [CrossRef]

Tobin, James. 1958. Estimation of relationships for limited dependent variables. Econometrica 26: 24-36. [CrossRef]

$\mathrm{Vu}, \mathrm{Ha}$, and Daehoon Nahm. 2013. The determinants of profit efficiency of banks in Vietnam. Journal of the Asia Pacific Economy 18: 615-31. [CrossRef]

Williams, Jonathan, and Nghia Nguyen. 2005. Financial liberalisation, crisis, and restructuring: A comparative study of bank performance and bank governance in South East Asia. Journal of Banking E Finance 29: 2119-54. [CrossRef]

World Bank. 2014. World Development Indicators 2014. Washington, DC: World Bank Publications, Available online: http:/ / databank.worldbank.org/data/home.aspx (accessed on 10 February 2019).

Chen, Xiaogang, Michael Skully, and Kym Brown. 2005. Banking efficiency in China: Application of DEA to pre-and post-deregulation eras: 1993-2000. China Economic Review 16: 229-45.

Xue, Mei, and Patrick T. Harker. 1999. Overcoming the Inherent Dependency of DEA Efficiency Scores: A Bootstrap Approach. Philadelphia: Wharton Financial Institutions Center, University of Pennsylvania. Unpublished Working Paper.

Zhang, Tiantian, and Kent Matthews. 2012. Efficiency convergence properties of Indonesian banks 1992-2007. Applied Financial Economics 22: 1465-78. [CrossRef]

(C) 2019 by the authors. Licensee MDPI, Basel, Switzerland. This article is an open access article distributed under the terms and conditions of the Creative Commons Attribution (CC BY) license (http:/ / creativecommons.org/licenses/by/4.0/). 